\title{
Conflicted Religionists: Measuring political backlash on salient issues
}

\author{
Sean Bock
}

Harvard University

\begin{abstract}
Scholars have pointed to politics as a key reason for why people leave religion, arguing that the national-level rise of the Christian Right has resulted in a "political backlash" of sorts, driving liberals and moderates away from their affiliations. Recent studies have advanced the political backlash model by emphasizing the process at lower levels, measuring broad political disagreement within congregations and subsequent disaffiliation among religionists. I argue that while studying political disagreement at the congregational level is a step in the right direction, the role of conflict on specific, salient issues has been underemphasized. Using data from the Baylor Religion Survey, I exploit a unique set of items to analyze what I call "conflicted religionists" - religionists who experience attitudinal conflict with their churches - and I measure conflict on two salient issues: same-sex marriage and abortion. I find that there is a considerable proportion of conflicted religionists on both issues and that the probability of experiencing conflict varies drastically across different groups in the sample. I further demonstrate that experiencing conflict is significantly associated with lower church attendance. I conclude with a discussion of the importance of salient issues for our understanding of political backlash and future disaffiliation.
\end{abstract}

Over the last half-century, the landscape of American religion has shifted dramatically. From the restructuring following World War Two (Wuthnow 1988) to the more recent polarization of religionists (Schnabel and Bock 2018), sociologists have studied changes in American religion that have had important consequences for both politics and social change more broadly. Perhaps the most notable and consequential change to American religion over the past several decades, though, has been the rapid rise of the unaffiliated or religious "nones" (Voas and Chaves 2016; Hout and Fischer 2014, 2002).

There has been a growing body of work on the disaffiliation of American religionists since the late-1980s (e.g., Voas and Chaves 2016; Hout and Fischer 2014, 2002). One prominent explanation has been the "political backlash" hypothesis, which points to the increased politicization of religion at the end of the 1980s and the rise of the Christian Right resulting in conflict between liberal and moderate parishioners and churches that espoused more conservative teachings - especially with family-related issues, such as abortion and homosexuality (Hout and Fischer 2014, 2002). This conflict, it goes, led to the subsequent disaffiliation of these religionists from churches, explaining in part the marked and continuous rise of religious "nones."

Most studies related to the political backlash hypothesis have studied this phenomenon by making post-disaffiliation observations at the aggregate level - that is, past studies have 
relied on descriptive trends among disaffiliated religionists over the past several decades. And thus, the conflict between religionists and churches - and the subsequent disaffiliation - has been surmised based on characteristics about those who have already dropped their religious affiliations: political liberals disaffiliated at a higher rate compared to other groups, and therefore political conflict was inferred as the culprit for the increased share of religious "nones."

However, this approach fails to measure an important link in the proposed mechanism, which is conflict between religionists and churches. Assuming that at any given moment there is a number of religionists who are conflicting with their churches and have not yet disaffiliated (i.e., it is unlikely that the process of experiencing attitudinal conflict and disaffiliation is instantaneous), one could measure these "conflicted religionists" and make descriptive observations about this group. The reason for the former approach in the literature is largely due to data limitations: it is difficult to obtain a measure of conflict between a religionist and his or her church. While recent work has made progress toward understanding political conflict at the congregational level (Djupe et al. 2018b; Djupe and Lewis 2015; Djupe 2011; Djupe and Gilbert 2008), these studies have under-emphasized specific, salient issues - such as abortion and same-sex marriage-and their role in declining religious identity and participation among American religionists. Directly studying perceived conflict on specific issues within congregations would provide further clarity as to the mechanisms underlying political backlash: rather than focusing on responses to national-level political movements (Hout and Fischer 2014) or broad political disagreement within congregations (Djupe et al. 2018b), a study of conflict on key issues provides a more contextual and realistic understanding of the relationship between politics and religious participation and identity.

The present study seeks to fill this gap by taking advantage of several unique items related to personal attitudes and church teachings to create a novel measure called "conflicted religionists." I use data from the Baylor Religion Survey (Wave II) to compare responses to questions about respondents' personal attitudes toward abortion and same-sex marriage and questions about the respondents' current church's attitudes toward these same issues. I identify respondents who perceive their personal views as different from the views of their current church, and I examine how this differs across important socio-demographic groups, such as: religious affiliation, political orientation, age, and educational attainment. A breakdown of conflicted religionists by socio-demographic variables helps to answer several questions abut the dynamics of political conflict among religionists. For instance: Are conflicted religionists actually on the political left? Are conflicted religionists concentrated in mainline and Catholic churches where the hierarchy has been at notable odds with the laity? Is political conflict largely a function of young people and a changing culture?

Under the political backlash model, we would expect conflict to lead to disaffiliation from churches. Given that the data consists of a single cross-section, I take the best available step here to understand the relationship between conflict and religious participation by measuring the association between conflicted religionists and church attendance. I do this in two ways: First, I measure the association between perceived conflict and church attendance to assess whether or not conflicted religionists attend church less frequently than non-conflicted religionists. Second, I take advantage of an item that asks respondents about their estimated church attendance frequency at age 12 to measure the association between perceived conflict 
and decreased church attendance from age 12. To ensure that the results are robust, both of these associations are measured using coarsened exact matching (CEM) techniques. ${ }^{1}$

To preview the findings, being a political liberal is clearly the most important predictor of conflict for both same-sex marriage and abortion, while a small proportion of conservatives are predicted to be conflicted religionists. While an expected result, this finding demonstrates that rather sorting into churches with similar views to their own (Wuthnow 1988), a sizable portion of liberal religionists remain in conservative churches and have perceived disagreements over important social issues - potentially a harbinger for sustained disaffiliation. Evangelicals stand out as having especially low-levels of predicted conflict, while mainliners and Catholics have a sizable proportion of predicted conflicted religionists - especially on same-sex marriage. Finally, I find that conflicted religion is negatively associated with church attendance: conflict on same-sex marriage is associated with an estimated $41.02 \%$ lower yearly church attendance, and conflict on abortion is associated with an estimated $60.35 \%$ lower yearly church attendance. Moreover, for both issues, conflict is associated with an increased probability of attending church less frequently than at age 12. Taken together, these results suggest that studying conflicted religionists provides important insight into the underlying mechanisms of political backlash.

\section{Background}

There has been a renewed interest in the study of religion by sociologists. With vast changes occurring in family structure, politics, demography, and social movements, sociologists have been interested in the effects of religion on behavior and attitudes of individuals (Bolzendahl and Brooks 2005). This interest has been especially strong in the United States, which has shown high levels of religious participation compared to other post-industrialized nations (Norris and Inglehart 2004). Despite this highly religious "exceptionalism", the greatest change to religion in the United States over the past few decades has been the drastic increase of the "nonreligious" (Hout and Fischer 2014, 2002). This trend has occurred much to the surprise of religion scholars.

\section{Religious restructuring model}

In his book, The Restructuring of American Religion, Wuthnow (1988) describes vast changes in the American religious landscape following World War Two. While the 1950's and preceding decades were defined by a strong Catholic, Protestant, and Jewish divide, the CivilRights Era effected a broader division between religious liberals and religious conservatives, thus making the traditional denominational demarcation increasingly irrelevant. The new division resulted in larger conflict within traditional denominations, leading to the rise of new sects and "special purpose groups" (Wuthnow 1988). With increased variety within

\footnotetext{
${ }^{1}$ To be clear, causal claims cannot be made about these association - I cannot preclude the possibility of reverse causality or other endogeneity concerns, which does not allow me to make causal claims about the relationship between attitude conflict and religious participation. However, we can measure the relationship between perceived conflict and church attendance and assess whether or not the found associations are consistent with the proposed political backlash mechanism.
} 
denominations, outlets were created for those with dissenting views who may have otherwise left the religion altogether. Such denominational diversity - and the lack of a single, national church, as seen in several European countries - has been pointed to as one of the central reasons for the United States' unique level of religious participation among Western industrialized nations (Chaves and Gorski 2001). The restructuring model suggests that we should see sustained religious vitality and little conflict within churches in the United States. Why, then, has the nonreligious population increased so dramatically?

\section{Political backlash model}

Surprisingly, the 1990's saw a drastic increase in the number of people identifying as "nonreligious," and this number has steadily increased since 2000 (Hout and Fischer 2014): 20\% of Americans claimed no religious preference in 2012, compared to $7 \%$ in 1987 . Hout and Fischer $(2014 ; 2002)$ offer the most detailed analysis of this important trend, identifying "unchurched believers," those who maintain their beliefs about God but claim no organized religious identity, as the most significant portion of the increasing "nonreligious" population. They also noticed that this increase of the "nonreligious" corresponded with the rise of the "Christian Right", a time when organized religions were receiving an unprecedented prominence in public discourse; ideas of religion, more specifically God and Christ, were cited as inspiration for politicians (Domke and Coe 2008; Hout and Fischer 2014, 2002). This entanglement of politics and religion - more specifically, the Right with Evangelicalism - they argue, ultimately drove people with conflicting political views (i.e., moderates and liberals) to disaffiliate. ${ }^{2}$ In short, Americans increasingly saw religion as at odds with their politics. Going against the conventional wisdom of religion scholars, Hout and Fischer, and others (Djupe et al. 2018b; Schnabel and Bock 2017; Patrikios 2008) have argued that this political backlash model is important for understanding the rapid disaffiliation seen over the last few decades.

While there is strong evidence for liberal political views leading to disaffiliation (Hout and Fischer 2014), these findings focus on aggregate level trends and infer a backlash to macro-level political phenomena (the rise of the Christian Right). That is, the evidence in favor of the political backlash model has been based on strong associations between liberal political ideology and disaffiliation, and thus the mechanism of political backlashattitudinal conflict - has been surmised on these descriptive aggregate trends.

Recent scholarship has advanced the political backlash model by further contextualizing the mechanism of attitudinal conflict at lower levels, such as the state (Djupe et al. 2018a) and church-levels (Djupe et al. 2018b; Djupe and Lewis 2015; Djupe 2011; Patrikios 2008; Djupe and Gilbert 2008). For instance, Djupe et al. (2018a) find evidence of higher rates of disaffiliation in states where there is an increased presence of the Christian Right, suggesting that political backlash may depend on context and the presence of salient controversy. Other studies have contextualized this dynamic further by focusing on backlash within specific congregations (Djupe et al. 2018b; Patrikios 2008). Patrikios (2008) found that Democrats have reduced their church attendance frequency in recent years because of their perceived

\footnotetext{
${ }^{2}$ Hout and Fischer also considered the effects of cohort replacement and secularization. They found that cohort replacement does explain some of the increased "nonreligious" category, while secularization, or decreased belief in God, does not.
} 
association between churches and Republican Party politics. Djupe et al. (2018b) continued the emphasis on specific congregational dynamics, providing the most thorough analysis of political backlash occurring at the congregational level. Their results provide robust evidence that perceived disagreement within congregations is the key driver of disaffiliation and that backlash over the Christian Right occurs amongst those who are more likely to experience disagreement in their congregations. Taken together, these results suggest that dynamics at the congregational level are key to our understanding of the mechanisms of political backlash. As Djupe et al. (2018b) note, the societal-level pattern of religious "nones" increasingly being concentrated on the political left is likely the aggregation of sets of localized differences (Djupe et al. 2018: 162).

Studies demonstrating the key role of congregational-level disagreement for political backlash have operationalized disagreement broadly as political differences with one's congregation or opposition to the Christian Right movement (Djupe et al. 2018b). While salient and controversial issues have been considered important parts of political backlash (e.g., The Christian Right made controversial issues, such as abortion and homosexuality, salient in the public sphere, thus driving religionists with dissenting views on those issues away from organized religion) disagreement on these issues - and their role in the process of political backlash - has gone unmeasured (Djupe et al. 2018a; Hout and Fischer 2014, 2002). Rather than general disagreement with one's congregation, a study of disagreement on specific, salient issues provides a more realistic picture of political backlash. For instance, due to social change or life course processes, a religionist may develop new attitudes on certain issues which are now at odds with the teachings of her church. In this scenario, it is possible that the religionist experiences conflict on a specific issue - or set of issues-but does not oppose all views of the Christian Right or Republican Party, for example. Here, rather than broad disagreement with one's church, it is disagreement on specific issues that matters for one's political-religious conflict and potential backlash. Further, an emphasis on specific issues allow for more flexibility in predicting political backlash across populations and over time: Different groups of people will conflict on different issues and social change may effect new salient issues that become points of conflict. Just as controversy over salient issues at the state level is an important predictor of political backlash (Djupe et al. 2018a), I argue here that the dynamic of specific salient issues within churches is vital to our understanding of this process, and it is this dynamic on which this article focuses.

In order to measure this group of conflicted religionists, the following logic must be assumed: the process of conflict and disaffiliation is not instantaneous (i.e., at any given point in time, there will be a group of religionists who conflict with their churches but have not yet disaffiliated.) ${ }^{3}$ Following this logic, it would be possible to analyze those who conflict with their churches and then study subsequent disaffiliation, allowing for a clear understanding of the political backlash process. While cross-sectional data do not lend themselves to measuring attitude conflict and disaffiliation directly, I can measure the association between conflicted religionists and other important behavior that is potentially related to disaffiliation, such as religious participation (Patrikios 2008). Again, as the process

\footnotetext{
${ }^{3}$ Importantly, I am not arguing that every person who experiences conflict will eventually disaffiliate. I am simply saying that those who do disaffiliate as a result of attitude conflict will not do so immediately following the experience of said conflict.
} 
of experiencing conflict and disaffiliation is not likely instantaneous, we could imagine a more likely sequence of events: 1) a religionist experiences attitude conflict with his or her church; 2) this conflict causes a change in his or her behavior related to said churchdeclined participation; and then 3) eventually the conflict leads to disaffiliation altogether. This sequence of events describes a more gradual process, whereby conflicted religionists slowly decline in their religious participation and then eventually leave their churches or affiliations altogether. Thus, a researcher could use a single cross-section of data to measure the association between conflicted religionists and religious participation, such as church attendance, to see if attitude conflict is associated with lower religious participation. While causal claims cannot be made about this association, we can assess whether or not the association is consistent with the model.

While an individual's beliefs may differ from that of his or her church on a wide range of social issues, this study focuses on abortion and same-sex marriage. These issues were chosen for at least five reasons. First, abortion and same-sex marriage are the only two social issues for which there are data about the views of both the respondent and his or her church. Though there are several other interesting and important issues to consider (e.g., environmentalism, marijuana legalization, pre-martial sex, and cohabitation), these two issues provide a good starting point for our understanding of conflicted religionists. Second, same-sex marriage and abortion are key family issues that have been championed by the Christian Right and are issues that Hout and Fischer explicitly identify as being contentious issues and possible culprits for the conflict seen in the 1990's (Djupe et al. 2018a; Hout and Fischer 2014, 2002). Third, both issues have been shown to be significantly important to people, politically (Schnabel 2016; Hoffmann and Johnson 2005; Jelen and Wilcox 2003; Manza and Brooks 1997; Olson et al. 2006). Fourth, examining these two issues provides a comparison between an issue that has seen rapid attitudinal change (same-sex marriage) (Baunach 2012; Gay et al. 2015; Powell et al. 2010; Schnabel 2016; Sherkat et al. 2010) and one that has seen little attitudinal change in the aggregate over the past few decades, but has become increasingly sorted along partisan lines (abortion) (Bolzendahl and Brooks 2005; Hoffmann and Johnson 2005; Jelen and Wilcox 2003). Fifth and finally, religion plays a major role in shaping attitudes about both issues (Adamczyk and Pitt 2009; Bolzendahl and Brooks 2005; Ellison et al. 2005; Jelen and Wilcox 2003; Olson et al. 2006; Wuthnow 1988).

\section{Where is conflicted religion concentrated?}

Building on established knowledge of same-sex marriage and abortion attitudes, this study focuses on four key variables to identify likely conflicted religionists: political orientation, religious tradition, education level, and age.

Political Orientation remains one of the most important factors for predicting attitudes toward social issues. By and large, liberals are much more likely to support same-sex marriage (Baunach 2012; Powell et al. 2010; Sherkat et al. 2010) and abortion (Jelen and Wilcox 2003). Furthermore, liberals, by a considerable margin, have been the most common group 
to disaffiliate over the past several decades (Djupe et al. 2018b; Hout and Fischer 2014, 2002). These patterns make liberals a likely and expected candidate for experiencing conflict. ${ }^{4}$

While I will examine the patterns among each of the predominant religious traditions in the U.S., this study is primarily focused on the comparison between Evangelicals and everybody else. Denominational lines - especially between Catholics and mainliners - have become increasingly irrelevant since the post-war era, and the most prominent demarcation, in terms of religious beliefs and practices, now lies between Evangelicals and non-Evangelicals (Schnabel and Bock 2018, 2017; Schnabel 2016; Wuthnow 1988). Moreover, Evangelicals have distinguished themselves by holding relatively stagnant, conservative social views, and, thus, there is likely little conflict among Evangelicals, because their Evangelical identities are contingent upon holding such conservative attitudes (Schnabel 2016).

Educational attainment has long been considered an important influence on social attitudes (Ohlander et al. 2005; Phelan et al. 1995). There is a classic notion of education being correlated with increased acceptance of nonconformity and civil liberties, which results in more liberal stances on social issues (Ohlander et al. 2005; Schoon et al. 2009). Despite drastic changes in attitudes toward same-sex marriage at the aggregate level, more highly educated Americans remain more tolerant of same-sex marriage (Ohlander et al. 2005; Sherkat et al. 2010). As such, it has been shown that educational attainment is still an important factor for predicting liberal social attitudes and, therefore, is likely related to one having conflicting views with his or her church. This prediction is further bolstered by data on the "unchurched believers," which shows that having more education is linked to a higher rate of disaffiliation (Hout and Fischer 2014, 2002).

With far-reaching changes over the past few decades, social scientists have given special attention to differences in attitudes between age groups (Voas and Chaves 2016; Baunach 2012; Hout and Fischer 2014, 2002; Powell et al. 2010; Schwadel 2010). The general trend reflects a younger population that is unprecedentedly tolerant, especially in regard to samesex issues, and an older population that is still widely in opposition to abortion (Jelen and Wilcox 2003) and same-sex marriage (Baunach 2012; Gay et al. 2015; Sherkat et al. 2010). Younger Americans show lower levels of religious activity in several regards: they are more likely to report no religious preference (Hout and Fischer 2014, 2002; Schwadel 2010); their church attendance is lower; they pray less often; and, they are the least likely to hold a literal interpretation of the bible (Gay et al. 2015). Some scholars have pointed to an increased value of autonomy among younger Americans, which leads to the fading of authoritative influence (e.g. religion), as the reason for such activity (Hout and Fischer 2014). As such, along with high support for same-sex marriage, young Americans are likely to conflict with their church's views.

\footnotetext{
${ }^{4}$ The importance of political orientation is clear, as moderates and liberals have the largest coefficients in the multivariable analyses - by far. But, adding political orientation to the models does not alter the patterns seen among the other covariates, suggesting that political orientation is not responsible for the patterns seen in religious tradition, for example.
} 


\section{Data, Measures, and Methods}

\section{Data}

The data used in this study are from the 2007 Baylor Religion Survey (Wave II), a national random sample of 1648 adults in the United States. This wave (Wave II) was administered and collected by the Gallup Organization, using a mixed-mode method of telephone and selfadministered mailed surveys in October and November of 2007. A random digit procedure was used to avoid various sources of bias (Baylor Religion Survey). According to the Baylor Religion Survey website, one can say with $95 \%$ confidence that the error attributable to sampling and other random effects could be plus or minus four percentage points (Baylor Religion Survey). ${ }^{5}$ See Table B1 for full-sample weighted descriptive statistic.

For the purposes of this paper, I only discuss analyses and results for a sub-sample, which is those who are currently in churches that have conservative attitudes toward samesex marriage and abortion (same-sex marriage: $N=920$; abortion: $N=1,003$ ). The attitudes of the church are based on the respondent's answers to questions about his or her current church's beliefs. I also analyzed conflicted religionists who attend churches with more liberal attitudes toward same-sex marriage and abortion, but as this group is very low in number (same-sex marriage: $n=132$; abortion: $n=63$ ), I do not discuss them in the main body of the paper. See Appendix D for analyses and further discussion of this group. While this group of conflicted religionists is interesting and should be evaluated further in future studies, studying conflicted religionists in conservative churches is more theoretically important given recent patterns of social change and is more relevant to the political backlash hypothesis.

\section{Dependent variables}

\section{Same-sex marriage conflict}

I measure conflict on same-sex marriage views by comparing two items. I compare one item that concerns the personal views toward same-sex marriage and one that concerns the respondent's church's views toward homosexual behavior. Respondents are asked to indicate their level of agreement (1= Strongly disagree; $2=$ Disagree; $3=$ Agree; $4=$ Strongly Agree) with the following question: "Please indicate your level of agreement with the following statements about homosexuals: Homosexuals should be allowed to marry." Responses were recoded $(1 / 2=1 ; 3 / 4=0)^{6}$ to create a dichotomous measure of personal same-sex marriage attitudes ( $1=$ opposed; $0=$ in favor). Respondents were asked to answer the following question about their church's views (Forbids=1; Strongly discourages=2; Somewhat discourages=3; Encourages=4; Isn't Concerned=5) toward homosexual behavior: "By your best guess, how would your current place of worship feel about each of the following? Homosexual behavior." Responses were recoded $(1 / 3=1 ; 4 / 5=0)$ to create a dichotomous measure $(1=$ opposed; $0=$ in favor) of respondents' churches' views on homosexual behavior.

\footnotetext{
${ }^{5}$ See Bader, C. F., Mencken, C., \& Froese (2007) for more information on the Baylor Religion Survey.

${ }^{6}$ The recoding notation in parentheses is from STATA. Forward slashes indicate "through." So, for example, " $1 / 2=1$ " indicates items one through item two were collapsed to equal one category (category " 1 ").
} 
While these items refer to two different topics (same-sex marriage and homosexual behavior), comparing these two items provides a good - the best available - measure of one's conflict with his or her church on same-sex marriage views for at least two reasons: (1) past research shows a strong correlation between broader views about homosexuality and views toward same-sex marriage (Powell et al. 2010), and (2) as this study is interested in the perceived conflict from the point of view of the individual, it is not unreasonable to assume that, in most cases, people would view their attitudes toward same-sex marriage to be incompatible with their church's views, based on the church's perceived feelings about homosexual behavior (i.e. if an individual believes that his or her church forbids homosexual behavior, they are not likely to perceive the church as supportive of same-same marriage).

\section{Abortion conflict}

To measure conflict on abortion attitudes, I compare respondents' answers to questions about both personal attitudes toward abortion and the teachings of their current churches. The survey asks the respondent how they feel $(1=$ Always wrong, $2=$ Almost always wrong, $3=$ Only wrong sometimes, $4=$ Not wrong at all) about the morality of the following: "Abortion, if the family cannot afford the child?" Responses were recoded $(1 / 2=1,3 / 4=0)$ to create a dichotomous measure $(1=$ opposed, $0=$ in favor $)$ of personal abortion views. Responses to this question were compared to the responses to the following item, which asks about the views $(1=$ Forbids, $2=$ Strongly discourages, $3=$ Somewhat discourages, $4=$ Encourages, $5=$ Isn't Concerned) of the respondent's current church: "By your best guess, how would your current place of worship feel about each of the following behaviors? Abortion" Responses were recoded $(1 / 3=1,4 / 5=0,8=$ missing), creating a dichotomous measure ( $1=$ opposed, $0=$ in favor) of church's views toward abortion.

The recoded responses to the items involving personal views of abortion and the views of the respondent's church were tabulated to create two categories of abortion attitude conflict: (1) abortion conflict in "conservative" churches (personal views=0; church's views=1) and (2) abortion conflict in "liberal" churches (personal views $=1$; church's views $=0$ ). Again, this study examines the people in the first category - those in conservative churches.

Comparing the responses to these items provides a good measure of conflict between one's personal views and the views of his or her church on abortion. While the two items do not align perfectly (i.e. the personal views question asks about the morality of abortion, while the church's views question asks about feelings toward abortion), moral approval or disapproval is largely responsible for one's attitudes toward abortion (Evans 2002; Hoffmann and Johnson 2005). Furthermore, these items provide the best-available measure of conflict, as the Baylor Religion Survey is the only known national survey that asks about both personal views and the views of individuals' churches on abortion. (See Appendix A for the distribution of responses given to the items used in the creation of each dependent variable.)

\section{Church attendance frequency}

I use two different outcomes to estimate the relationship between experiencing conflict and church attendance frequency. The first is church attendance frequency, and the second is a measure of change in church attendance frequency from the age 12 . 
Church attendance frequency was originally measured in the survey as an ordinal scale, ranging from 0) "never" to 7) "several times a week". For interpretability, I transform this measure into an interval scale, approximating days of attendance per year. I then logtransform the result. ${ }^{7}$

Change in church attendance frequency. Given that the data are a single cross-sectional, I cannot measure over-time processes. However, I am able to take advantage of a measure of change in church attendance from age 12 as a second way of estimating the association between experiencing conflict and church participation. This variable was created by subtracting estimated church attendance frequency at age 12 from current level of church attendance. The resultant measure was then dichotomized: 1=lower attendance frequency than at age 12; $0=$ greater or equal attendance frequency compared to age 12 . While not perfect (i.e., estimates of R's church attendance frequency at age 12 may be biased upward or downward), this measure allows for the most robust estimate of an over-time component available with a single cross-section of data.

\section{Key independent variables}

Political orientation is measured by respondent's answers to the question "How would you describe yourself politically?". Responses range from 1 ("extremely conservative") to 7 ("extremely liberal"). In line with Hout and Fischer's 2002 classification, I use a three-way political orientation variable: 1) conservative 2) moderate and 3) liberal.

Religious tradition is measured by the commonly used "RELTRAD" variable. This variable was created from a larger pool of self-reported religious affiliation to further categorize respondents into seven categories based on the Steensland et al. (2000) religious categorization scheme: Evangelical protestant, Black Protestant, Mainline Protestant, Catholic, Jewish, other, and none. Because of small cell counts, I drop Jews and the small number of religious "nones" who attended a church. While unfortunate, I do not think this limiting of religious traditions substantially harms the substantive findings of this paper-especially as I am most concerned with the evangelical/non-evangelical comparison. ${ }^{8}$

Education is measured by self-reported highest level of education, ranging from 1 ("less than high school) to 5 ("graduate degree." ). I collapse responses into three categories: Low (HS or less), Medium (Some college), and High (college degree or higher).

Age is measured in years.

\section{Control variables}

This study controls for key demographic characteristics that may affect one's likelihood of conflicting with his or her church on same-sex marriage and abortion attitudes. These variables were chosen based on what is standard in the literature related to public opinion on

\footnotetext{
${ }^{7} \mathrm{~A}$ constant is added in the $\log$ transformation because of zero values for " "never attend." While the use of interval scales as a continuous outcome variable in analyses is typically a cause for concern, this transformation can be thought of as similar to that which is commonly done with translating categorical income brackets into a nominal income variable. See Lim and Putnam's 2010 American Sociological Review paper for an example of this type of translation being used with church attendance (Lim and Putnam 2010).

${ }^{8}$ Patterns among the small number of Jews and nones dropped from analyses are available upon request.
} 
same-sex marriage and abortion (Jelen and Wilcox 2003; Ohlander et al. 2005). The controls include sex (female=1), rural/urban (city, suburb, town, rural), region (East, Midwest, South, West), and race (white, non-white). ${ }^{9}$ I also include a control for partisan identification, measured as Republican, Independent, and Democrat, as well as a control for religiosity ( $1=$ "very religious" $0=$ "not very religious"). ${ }^{10}$

\section{Analytic strategy}

The primary goals of the analyses are to understand the prevalence of conflicted religionists overall, to identify the groups most likely to experience attitude conflict, and to identify the association between conflicted religion and church attendance. To this end, I use bivariate logistic regression to establish baseline probabilities of experiencing conflict by each key covariate. I then turn to multivariable analyses to control for demographic factors and identify the most significant variables predicting same-sex marriage and abortion attitudinal conflict. All results from logistic regressions are presented as predicted probabilities as predictions provide optimal interoperability and allow for better cross-model comparisons; further, as I am interested in the probability of perceived conflict, so predictions present the results on their "natural scale" (Mize et al. 2019).

I measure the relationship between experiencing conflict and church attendance frequency with two approaches: First, I simply compare church attendance frequency between conflicted religionists and those not experiencing conflict by regressing church attendance frequency on a dummy variable for experiencing conflict. Second, I compare the difference between respondent's current church attendance frequency and his or her church attendance frequency at age twelve. While not perfect, this approach gives insight into the over-time dynamics of conflict and its association with church participation ${ }^{11}$. As this variable is binary ( $1=$ current attendance is lower than at age $12,0=$ current attendance is equal to or greater than attendance at age 12), I estimate the probability of attending church less frequently with logistic regression. For both of these approaches, I use coarsened exact matching (CEM) to robustly identify the associations; because I am concerned with the association between a single independent variable and an outcome with both of these approaches, rather than

\footnotetext{
${ }^{9}$ Race is dichotomized due to the high correlation between African Americans and Black Protestants. Including both the race variable with all available categories and religious tradition in multivariable analyses inflates both the variance and coefficient for Black Protestants. Collapsing the race category avoids this issue but at the cost of a loss of information. However, given that patterns among racial categories are relatively null, I believe the dichotomization of the race variable is the appropriate approach to handling the high collinearity.

${ }^{10} \mathrm{I}$ do not include a control for income because of severe missingness on this item. Though an unfortunate omission, education provides an adequate measure of socioeconomic status. Moreover, the substantive findings do not notably change with the inclusion of income as a control.

${ }^{11}$ Respondent's estimates of their past church attendance may be off-either lower or higher-which would bias the estimated associations. Further, assuming that respondent's church attendance at age twelve is accurate, we still cannot establish a causal relationship between perceived conflict and decreased church attendance, because we do not know the timing of the experienced conflict, not do we know the timing of the decreased church attendance. Nevertheless, this measure provides another way to capture the association between perceived conflict and church attendance, along with the simple association between conflicted religionists and current attendance.
} 
the partial contribution of several covariates, matching allows for the most robust measure of that association (Morgan and Winship 2014).

Matching is a nonparametric technique used to achieve better balance between "treated" and "control" groups, thus reducing the confounding influence of control variables in the data. CEM is a monotonic imbalance bounding matching technique that allows users to explicitly bound the data ex ante (See Iacus et al. (2009) for more on CEM and its implementation in STATA.) I run two separate matching procedures for each attendance measure, one for samesex marriage conflict and one for abortion conflict. In each of these models, being a conflicted religionist is the "treatement." I then regress both church attendance frequency measures on each type of conflict with the corresponding matching weights, allowing me to robustly identify the associations. While matching techniques are typically used in the context of causal inference, I want to stress here that the data at hand do not allow me to make causal claims about the relationship between attitude conflict and religious participation ${ }^{12}$; however, exploiting all available attendance measures, along with matching, does allow for the most robust identification of this relationship - an important first step for better understanding attitude conflict and political backlash.

Sampling weights were used in the generation of all descriptive statistics. I do not include weights, however, for the multivariate analyses, allowing for more precise, unbiased estimates (Winship and Radbill 1994). As a robustness check, I tested the difference between the weighted and unweighted coefficients (using the WGTTEST in STATA), as proposed by Dumouchel and Duncan (1983). The coefficients in each of the unweighted and weighted models are not significantly different at the 0.05 level, indicating good model specification and further justifying the exclusion of sampling weights in the multivariate analyses (See Winship and Radbill (1994)).

\section{Results}

Figure 1 displays predicted probabilities of conflicting by each covariate. Gray points are unadjusted estimates from baseline models (without controls) and black points display adjusted predictions, estimated from models including controls. Error bars display confidence $95 \%$ intervals to demonstrate uncertainty in the estimates. ${ }^{13}$ The left panels show predictions for conflict on abortion, right panels show predictions for same-sex marriage conflict. I discuss each outcome in turn.

\section{Same-sex marriage attitude conflict}

First, about a quarter of people conflict with their churches on same-sex marriage (26\%). This is an initial and important result. It indicates that within the Baylor sample, a sizable proportion of individuals attend a church that is at odds with their personal views on samesex marriage.

There is a clear association between people's political ideologies and attitude conflict: The probability of conflicting on same-sex marriage steadily increases as we move from the

\footnotetext{
${ }^{12}$ Matching does not preclude the possibility of reverse causality or other endogeneity concerns

${ }^{13}$ Note that these error bars do not indicate significance tests between estimates.
} 
political right to left, with liberals having the highest baseline probability of conflicting at 0.63, compared to conservatives at 0.11. While attenuated, this pattern also holds in the full model, suggesting the clear importance of political ideology for predicting conflict on same-sex marriage.

We see interesting differences among religious traditions for conflict on same-sex marriage attitudes in the baseline model. Catholics and mainline Protestants show substantially larger probabilities of conflict compared to other religious traditions (Catholics $=0.40$, mainline Protestants $=0.31$, with Catholics showing the largest probability of experiencing conflict. ${ }^{14}$ As expected, Evangelicals are experiencing conflict the least among religious traditions (0.15), while 0.17 of religious others are conflicted. About 0.20 of Black Protestants are conflicted. When controls are added, the gap between Catholics and mainliners disappears, and the difference between these groups, while still significant, shrinks. Interestingly, the probability of conflicting increases for Evangelicals in the full model compared to the baseline model, suggesting that the demographic and political makeup of Evangelicals is driving the baseline probability of conflicting down.

Surprisingly, the patterns among education levels are not definitive. While those religionists with medium and high levels of education do have higher probabilities of conflicting compared to those with a low level of education in the baseline model, the difference is slight, and this difference only gets smaller with the adjusted predictions. If anything, there is a slight curvilinear pattern in the adjusted model, with those with medium levels of education predicted to conflict the most.

In both the baseline and full models, there is a relatively flat trend in the probability of conflicting across the age distribution, with a decline between 18 and 30-year-olds. ${ }^{15}$ Given the relative strong support among younger Americans for same-sex marriage in 2007, this trend makes sense. While younger Americans do appear to conflict more, the gap is smaller than what was expected - overall, there does not appear to be a strong association between conflict on same-sex marriage and age. (See Appendix C for patterns among control variables.)

In sum, one's political views appear to be the strongest predictor of conflict on same-sex marriage, as we would expect. Evangelicals demonstrate a lower probability of conflicting compared to mainliners and Catholics, and this difference holds in the adjusted models. Younger religionists are more likely to experience conflict on same-sex marriage compared to older religionists, but the relationship is weaker than expected. Finally, there is no clear trend among levels of educational attainment.

\footnotetext{
${ }^{14}$ There is some evidence of an interaction effect between age and religious tradition, suggesting Catholics are less likely to conflict as they age, while other religious traditions show smaller or little variation with age. I do not discuss this finding at length in this paper, as I came to this finding post-hoc and had no prior theoretical underpinnings as regards religious traditions and age interactions. Moreover, the small counts within each religious tradition make conclusions about such effects tenuous at best. This could potentially be an interesting point of study in future research. Graphical representations showing these effects are available upon request.

${ }^{15}$ To allow for more flexibility across the distribution, the age models were estimated with binomial and cubic polynomial terms. Higher polynomial terms did not add further statistical or substantive value.
} 
Figure 1: Predicted probabilities of experiencing conflict by key covariates

Political orientation

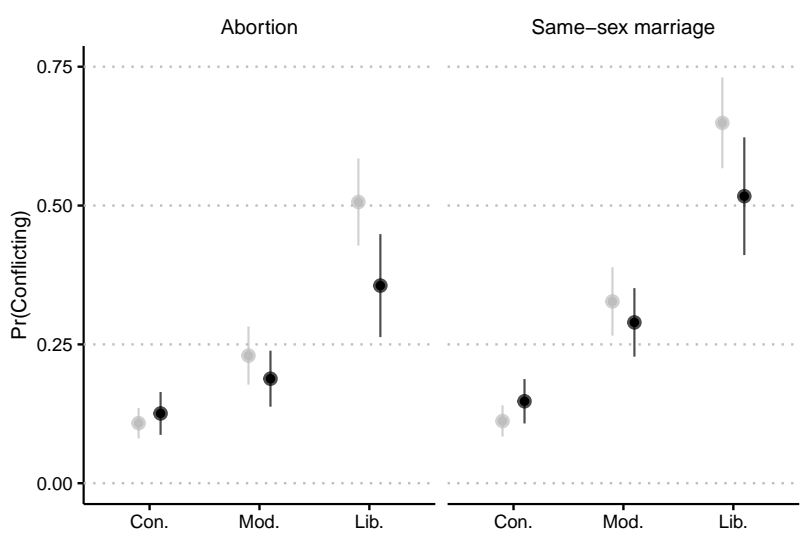

Education Level

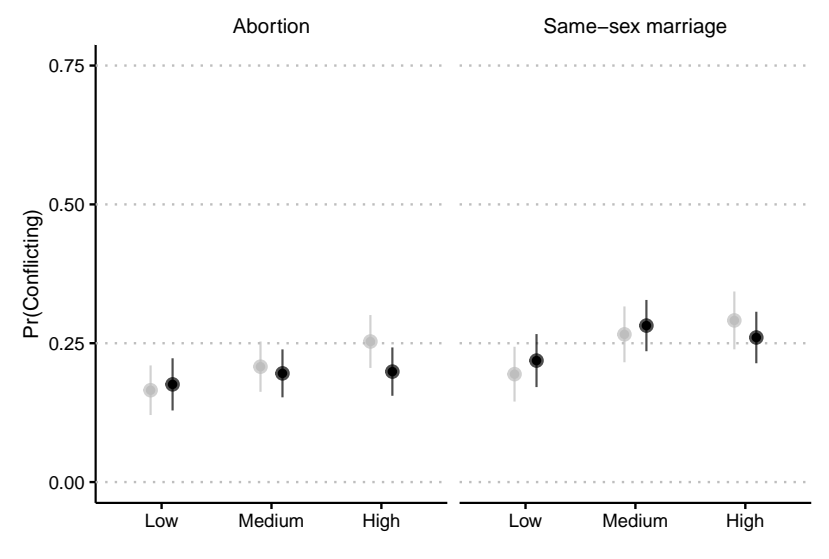

Religious tradition

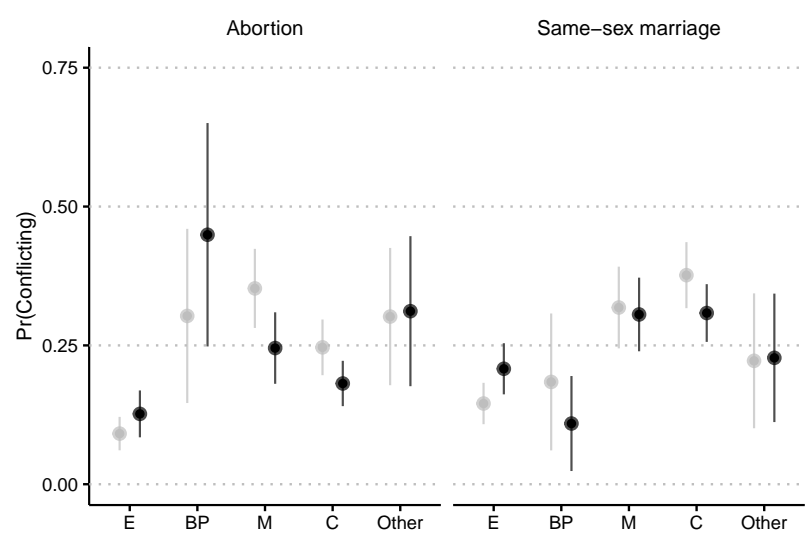

Age

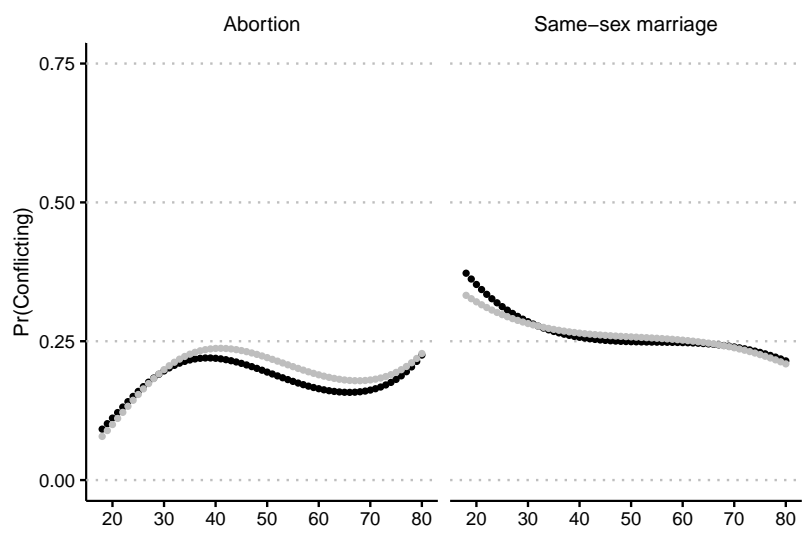

Note: Con. $=$ Conservative, Mod. $=$ Moderate, Lib. $=$ Liberal, E=Evangelical, BP=Black Protestant, $M=$ Mainline Protestant, $C=$ Catholic

\section{Abortion attitude conflict}

Conflict on abortion shows similar patterns, with a few notable differences. The overall proportion of people who conflict is slightly lower at 0.21 (compared to 0.26 for same-sex marriage). This difference is small but illustrative of the different natures of these two social issues: More rapidly changing attitudes, such as with same-sex marriage, create more opportunity for conflict, as attitudinal change at the individual level is more likely to occur.

Consistent with the findings on same-sex marriage, political ideology is the strongest predictor of conflict: Liberals are conflicting the most of any group ( 0.50), followed by markedly lower probabilities for moderates and conservatives. Compared to same-sex marriage, the gap between moderates and conservatives is much smaller. This pattern holds in the full model, with the largest difference being an attenuated prediction for liberals - similar to the attenuation in the model for same-sex marriage conflict.

Among religious traditions, we see notably different patterns compared to same-sex marriage. First, Black Protestants stand apart as the most likely to experience conflict. This result makes sense in light of the African-American community's long-standing support for 
abortion rights. The gap between Evangelicals and every other denomination is more notable with abortion compared to same-sex marriage, and this result holds for baseline and full models. As we would expect, given the church's clear anti-abortion doctrine, Catholics demonstrate a lower probability of experiencing conflict on abortion compared to same-sex marriage - still, nearly a quarter of Catholics in this sample disagree with their church's teachings on abortion.

Education shows a similar, null pattern for abortion as with same-sex marriage. There is a slight increase in probability from low to high education, but these differences are small for both the adjusted and unadjusted models.

There is a curvilinear trend in the probability of experiencing conflict across the age distribution, with a peak around 40 years of age. This trend among younger Americans runs opposite to what is seen here with same-sex marriage: 18 to 30 -year-olds are the least likely to experience conflict on abortion. One possible explanation may, again, rest in the different life courses of these two social issues, in that abortion is long-running issue on which religionists have already firmly sorted. While the relationship between same-sex marriage and religious identity is still in flux in 2007, the central position of abortion in the identities of religionists is firmly established at this time. Thus, it may be that younger Americans - a group who is increasingly choosing their religious identities - have simply sorted out of churches who have more conservative views on abortion. (Again, see Appendix C for patterns among control variables)

To recap, religionists' political beliefs and identities are the strongest predictors of experiencing conflict on abortion and same-sex marriage. There are distinct differences among religious traditions for both issues, with Evangelicals standing apart as especially unlikely to experience conflict - especially for abortion. Finally, the patterns among young Americans differ between these two issues: while young Americans are the most likely to conflict on same-sex marriage, they are the least likely to experience conflict on abortion, pointing to the different natures of these two issues.

\section{How does conflict relate to church attendance?}

I have thus far shown the probabilities of experiencing conflict by each key variable. But how does conflict associate with church attendance frequency? In the political backlash model, the expectation is that conflict leads to reduced attendance frequency and, eventually, disaffiliation altogether. Thus, we would expect conflicted religion to be associated with lower church attendance frequency. I estimate this association with two different approaches: First, I estimate the predicted decrease in church attendance frequency for a conflicted religionist versus a non-conflicted religionist. Next, I display the average marginal effect (AME) of conflicted religion on decreased church attendance from age 12 (i.e., these estimates show the difference in probability of attending church less frequently than the respondent did at age 12 for conflicted religionists versus non-conflicted religionists.)

Figure 2 shows the predicted logged church attendance for a conflicted religionists compared to non-conflicted religionists. As the outcome variable (church attendance frequency) is logged, a simple transformation of the coefficients allows for a convenient interpretation of a percent increase or decrease in year number of days attended at church for a conflicted religionists compared to a non-conflicted religionists: $(1-\exp (b)) * 100$. I present results from 
Figure 2: Predicting church attendance frequency by conflicted religion
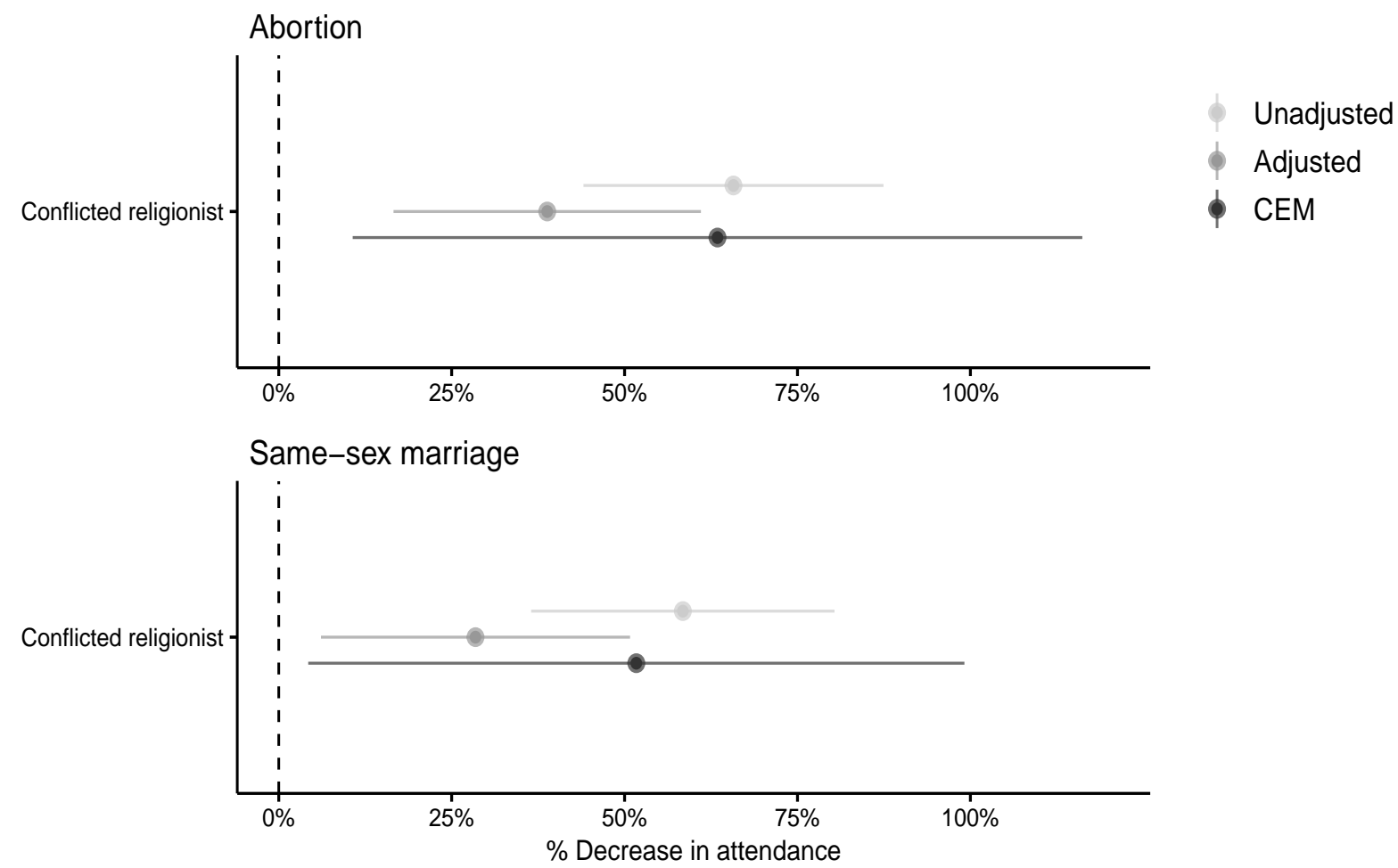

Figure 3: Predicting difference in church attendance frequency from age 12
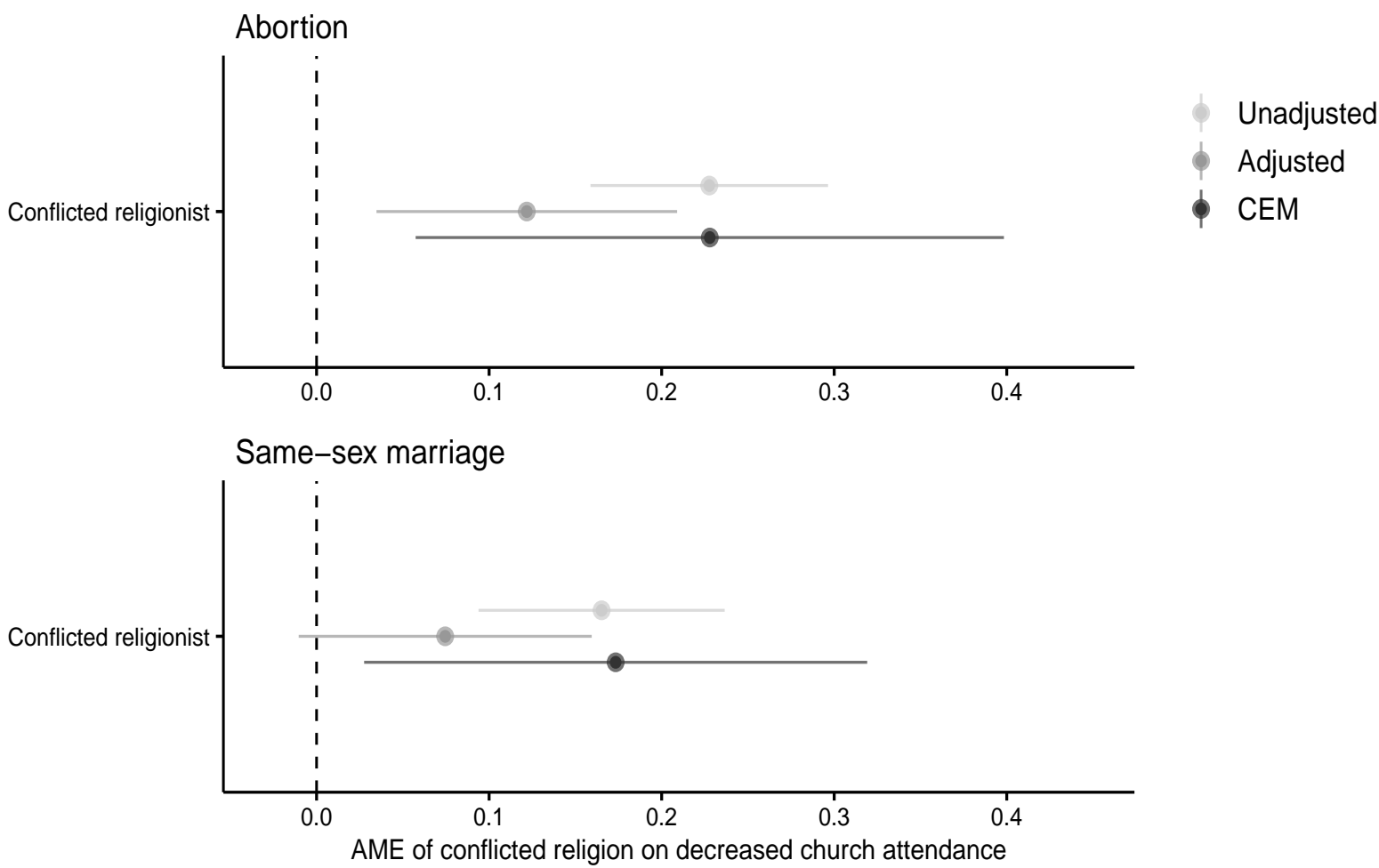
three different modeling approaches. The main result, "CEM", is the coefficient estimated after the Coarsened Exact Matching process; I include results from two other models: a baseline estimate from an OLS model without controls and an adjusted estimate model that includes controls. I include the latter as a point of comparison to demonstrate the correction done by the CEM model. Estimates are statistically significant at the $95 \%$ level if the error bar does not cross the dashed vertical line at $0 \%{ }^{16}$

As expected, the coefficients for both same-sex marriage and abortion are negative and significant at the 0.05 level, indicating lower church attendance for conflicted religionists on both issues; this result holds in both of the robustness checks, as well. Those conflicted on same-sex marriage have an estimated $51 \%$ lower yearly church attendance rate, and those conflicted on abortion have an estimated $62 \%$ lower yearly church attendance rate. This is a clear and robust finding that adds support to the proposed mechanism of attitudinal conflict leading to decreased church involvement (measured here as attendance). Simply put, a religionist who disagrees with his or her church on abortion or same-sex marriage is predicted to attend church significantly fewer days each year, a markedly lower level of religious participation than non-conflicted religionists.

I now turn to my second estimation approach. Figure 3 displays the AME of experiencing conflict on attending church less frequently than at age 12. As with figure 2, I include three different models, with the main estimate coming from the CEM model. Again, we see evidence of a negative association between experiencing conflict and church attendance frequency for both same-sex marriage and abortion. The probability of attending church less frequently than at age 12 increases by about 0.18 for same-sex marriage conflict and about 0.23 for abortion conflict, and both estimates reach significance at the $95 \%$ level. While these results do not allow me to make a causal claim about the relationship between attitude conflict and church attendance, the associations identified here are consistent with the proposed mechanism of conflict leading to reduced church involvement (Patrikios 2008). ${ }^{17}$

The results above demonstrate that experiencing conflict is negatively associated with church attendance on average. But does this result vary by key covariates? In other words, is the negative association between experiencing conflict and lower church attendance frequency conditional on other variables? To test this, Figure 4 plots the results from several models that regress church attendance frequency on a conflicted religionist $\mathrm{X}$ covariate interaction. As with Figure 2, the y-axis displays the $\%$ decrease in church attendance frequency for a conflicted religionist versus a non-conflicted religionist. Gray bars correspond to predictions from baseline models without controls, and black bars correspond to predictions from models with controls. Because cell sizes are relatively small here (and note that the cells sizes

\footnotetext{
${ }^{16}$ The main result is from the OLS estimates of logged church attendance frequency on conflicted religionists. These regressions were run after the CEM process, including the matching weights, and thus the coefficients represent the adjusted association of conflicted religion and attendance. Each conflict variable was matched on age, sex, region, urban/rural, education, political orientation, party identification, religious tradition, and religiosity. The CEM process produced greater balance on both conflict variables; $L 1$ provides a measure of balance on covariates, and thus a reduction in $L 1$ after the matching process indicates greater balance. Same-sex marriage conflict had an $L 1$ reduction of 0.079 , and abortion conflict had an $L 1$ reduction of 0.0745 .

${ }^{17}$ Note that AME in the adjusted model for same-sex marriage just fails to meet significance at the $95 \%$ level. Considering the difference from the results of the CEM model, this is likely an indication of substantial imbalance among covariates in this model compared to the abortion model.
} 
Figure 4: Predicting church attendance frequency by conflictXcovariate interactions

Political orientation

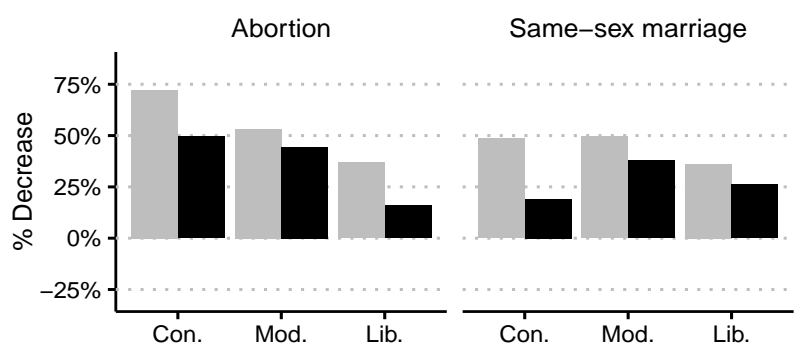

Education Level

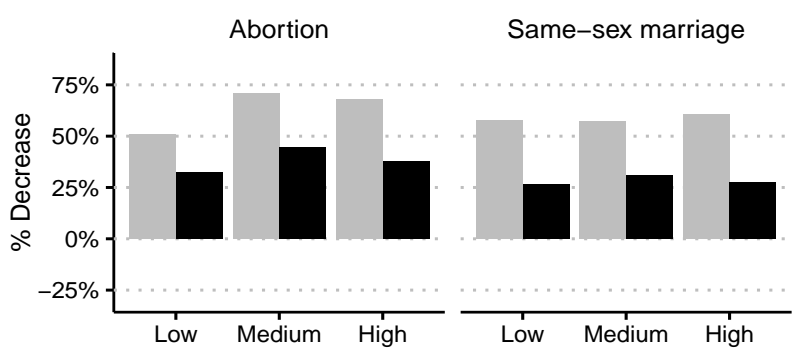

Religious tradition

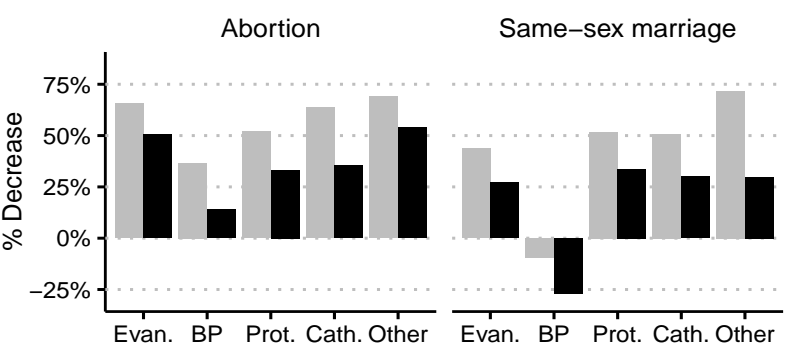

Age

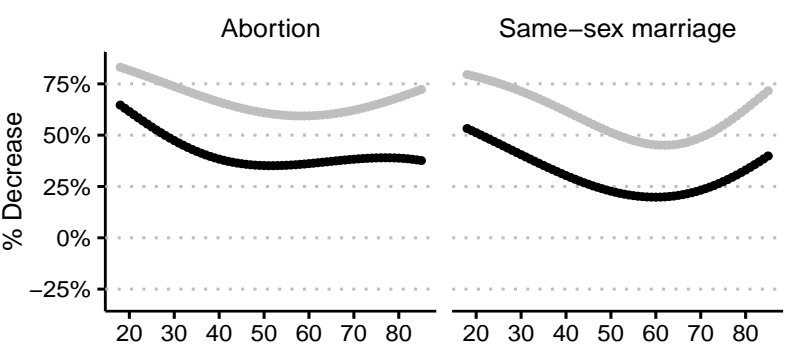

Model • Unadjusted • Adjusted

drastically vary across categories due to the dispersion of conflicted religionists in the sample), most of these predictions fail to meet statistical significance, and I have omitted errors to avoid distraction. ${ }^{18}$ I thus interpret these results with caution, but the descriptive patterns are revealing, nonetheless.

Overall, the negative association between experiencing conflict and church attendance holds across these subgroups, with the one exception of Black Protestants, who actually have higher church attendance if they conflict with their church on same-sex marriage. Interestingly, the pattern among political orientation categories differs between abortion and same-sex marriage. For abortion, there appears to be a steady decline in the negative association between conflict and church attendance going form the political right to left. In other words, if a religionist is conservative and disagrees with her church on abortion, she is predicted to attend church less frequently compared to political liberals. Finally, there appears to be an interaction between age and experiencing conflict, with younger conflicted religionists attending church less frequently than older conflicted religionists. I discuss these results more below.

\footnotetext{
${ }^{18}$ See Figure $\mathrm{C} 2$ for predictions including error bars
} 


\section{Discussion and Conclusion}

For decades, the conventional wisdom among scholars of American religion has been that a restructuring took place in the post-war era in which new outlets (new sects and religious groups) were created, reflecting a diversifying group of religionists (Wuthnow 1988). As such, religionists - we would expect - would have selected into churches with which they have attitudinal agreement. Yet, over the past few decades, we have seen a rapid increase in the number of nonreligious people, and some have pointed to political backlash as the culprit for the unexpected rate of disaffiliation (Djupe et al. 2018b; Hout and Fischer 2014; Patrikios 2008; Hout and Fischer 2002). While recent work has advanced the political backlash model by emphasizing lower-level processes (Djupe et al. 2018b,a), the role of disagreement on specific, salient issues has been underemphasized. This paper adds to the growing body of work that studies political backlash at the congregational level by analyzing "conflicted religionists" and this group's association with church attendance. The results demonstrate several important findings.

\section{Measuring conflicted religionists}

Political orientation is clearly the most important factor for predicting whether or not someone is a conflicted religionist. Moreover, conservatives are unlikely to conflict with their churches on these issues. In discordance with expectations of the restructuring model, these dissenters have not filtered into churches with more liberal views but have rather remained (for now) conflicted religionists. Moreover, the fact that conservatives are conflicting very little with their churches on these important issues suggests that American religion may increasingly be represented by political and religious conservatives - a consequential pattern for religion and politics in the U.S. (Schnabel and Bock 2018, 2017).

In line with other recent work, the results suggest that the most important denominational distinction in the United States may be between Evangelicals and everyone else. Even after controlling for political ideology and other variables, Evangelicals stand apart from other groups as the least conflicted religionists. Compared to other denominations, few evangelicals disagree with their churches on these keys issues. This is consistent with the well-documented finding in longitudinal studies that relatively few Evangelicals have disaffiliated over the past several decades (Schnabel and Bock 2018, 2017). As Schnabel and Bock $(2018$, 2017) have argued, the result has been an American religious landscape that has become increasingly polarized along religious "intensity" lines, with moderate religion steadily declining and "intense" religion persisting.

Beyond the important Evangelical/non-Evangelical distinction, the findings regarding Catholics should also be noted. Catholics were the only group to have a significantly higher predicted level of conflict on same-sex marriage compared to Evangelicals. This finding is in line with the unparalleled disaffiliation (Hout and Fischer 2014) and overall changing sentiments among Catholics (Smith et al. 2014). It is also possible that the apparent conflict among Catholics is not necessarily due to unique attitudinal changes but rather is the result of a lack of congregational variety. Compared to Mainline Protestants, for instance, dissenting Catholics do not have an outlet within the Catholic church and are thus forced to either (1) remain as a conflicted religionists, (2) switch out of the Catholic church, or (3) disaffiliate 
from religion altogether. Yet, while Catholics do stand out on same-sex marriage conflict, it should be noted that Catholics do not statistically differ from Mainline Protestants across both issues, suggestive of the sort of denominational converging argued by Wuthnow (1988).

While the probability of experiencing conflict on same-sex marriage is highest among younger Americans, there is a curvilinear relationship between age and conflict on abortion. In fact, younger Americans are the least likely to experience conflict on abortion. Likewise, highly education religionists are not particularly likely to experience conflict on either issue. Why might this be? One scenario could be that most of the young Americans and the highly educated with more liberal views have already disaffiliated, thus leaving a small proportion of these people in conservative churches. Consequentially, there would be fewer young and highly educated people left to conflict. This scenario is supported by what we know about disaffiliation trends - younger Americans and the highly educated are among the most likely groups to have disaffiliated in the past few decades (Hout and Fischer 2014, 2002). This scenario is also supported by the data used in this study: 18-30 year-olds make up the largest proportion of the nonreligious. Another possible explanation is that young Americans and the highly educated are more likely to have switched into churches with which they share more progressive same-sex marriage views. This seems especially likely for higher educated people, as they have been shown to be more likely to select their churches rather than remaining in the church of their parents, for example (Schwadel 2011). This scenario is also supported by the data from this study: higher educated people, by far, make up the largest percentage of those in churches with more liberal views. Thus, this explanation would suggest that perhaps along age and educational lines, Wuthnow's (1988) denominational filtering remains true.

\section{Conflicted religionists, salient issues, and declined church atten- dance}

The political backlash model posits that attitudinal conflict can eventually lead to disaffiliation. Given that the available data is a single cross-section, I am unable make claims about conflict leading to eventual disaffiliation. However, I have proposed here that while we cannot observe disaffiliation, we could reasonably expect the effects of attitudinal conflict to take place gradually, whereby conflicted religionists demonstrate decreased religious participation before possibly disaffiliating altogether. In this instance, conflicted religion is a stepping-stone to disaffiliation. The results show a clear and strong association between attitudinal conflict and lower church attendance, for both abortion and same-sex marriage conflict. Moreover, this negative association is fairly stable across key covariates with a few notables exceptions. The negative association between conflict on abortion and church attendance appears to be stronger among conservatives compared to liberals. This is an unexpected finding but is broadly consistent with Djupe et al. (2018b)'s finding that backlash to the Christian Right primarily occurred among Republican Evangelicals because they were the most likely to be confronted with politics of the Christian Right. Perhaps conservative conflicted religionists tend to attend churches in which abortion politics are made more salient in their congregations compared to liberal religionists. ${ }^{19}$ The negative association

\footnotetext{
${ }^{19}$ Again, given the small cell sizes, I am cautious to draw any strong conclusions about these results.
} 
between church attendance and conflict is also notably higher among younger Americans for both abortion and same-sex marriage. So while younger Americans are not more likely to experience conflict on abortion compared to older Americans, if they do, it may affect their religious participation much more strongly.

Taken together, these analyses bolster the political backlash hypothesis: disagreeing with one's church on important issues, such as same-sex marriage and abortion, is associated with lower church participation (measured here as church attendance). While past studies have demonstrated the mechanism of political disagreement for disaffiliation at the congregational level, I have argued that they underemphasize the importance of specific issues for this process. Different patterns among conflicted religionists on abortion and same-sex marriage point to the fact that political disagreement can take place along several dimensions and occur differently for different religionists. Rather than broad political disagreement (Djupe and Gilbert 2008), opposition to the "Christian Right" (Hout and Fischer 2014, 2002), or contention with Republican party politics (Patrikios 2008), political backlash may occur as a process of religionists experiencing irreconcilable conflict with their congregation on salient issues that are important to them. A focus on conflict over salient issues provides a broader lens for understanding political backlash - one that takes into account the relationship between political-cultural change and churches' responses to change. The issue of same-sex marriage highlights this point. There was unprecedented rapid change in support for samesex marriage (Powell et al. 2010), which created the perfect conditions for increased numbers of conflicted religionists: An increased share of the population had pro-same-sex marriage views, while the doctrines of most religionists' churches had not adapted accordingly - the cultural change occurred too quickly.

While the political backlash literature has focused on the influence of the Christian Right to explain recent disaffiliation trends, my analysis and emphasis on salient issues suggests that any socio-political issue has the potential to drive backlash if the conditions are right. And thus the cycle of political backlash my continue to occur in the future, but perhaps with a different set of salient issues. Further, as has been well established, the current political backlash has occurred primarily among political liberals, and it is likely that this trend will continue: Increasingly progressive views are often at odds with traditional doctrine in organized religion, and so it will likely continue to be political liberals who experience conflict and eventually disaffiliate. Such a process would result in the continued "exceptional" (compared to other wealthy democracies) American religious landscape that is primarily concentrated by the most ardent practitioners and believers (Schnabel and Bock 2018, 2017).

\section{Limitations and future research}

There are several limitations to this study that should be noted. First, while I believe measuring the relationship between conflicted religionists and church attendance allows for the best available assessment of the consequences of attitude conflict, I cannot make causal claims about this relationship. I have used matching techniques - usually used in the causal inference framework - to robustly identify the association of interest, but that does not preclude the possibility of endogeneity concerns. It could be that conflicted religionists do not become conflicted and then attend church less often but that certain religionists already at- 
tend church less often and then develop conflicting attitudes more easily because they are not as attached to the church. While this is an important concern, it does not obfuscate the association found here: that conflicting with one's church is associated with lower participation. Regardless of the causal direction, this association points to the apparent incompatibility of holding social views that are at odds with the teachings of one's church and maintaining strong participation with said church.

Second, the data used in this study are from 2007, but there have been some important legal and social changes since that time: Same-sex marriage approval has increased substantially, and, most importantly, it has become legal at the national level. If anything, then, the estimates of the prevalence of attitude conflict provided in the present study may be conservative. Nevertheless, the aim of this study is to emphasize the importance of salient issues for the process of political backlash. As such, any point in time since the beginning of the recent wave of political backlash (the early 1990s) serves as a good sample frame with which to study this phenomenon. What matters is the particular issues analyzed and their relevant saliency at the time point studied. In this case, 2007 serves as an ideal time to study same-sex marriage beliefs and their role in backlash, given the topic's growing prominence in social and political discourse at that time (Powell et al. 2010).

Third, while the theoretical framework discussed throughout the paper is concerned with attitude conflict eventually leading to disaffiliation, that is not a necessary process - it may be that conflicted religionists won't necessarily disaffiliate. Hirchman's (1970) concept of "Exit, Voice, and Loyalty" provides a good framing for the potential paths of a conflicted religionist: She may experience conflict and leave the church all together ("Exit"); She may attempt to stay but change the teachings or the views of the church on the issue on which she is conflicted ("Voice"); Or, she may remain in the church while continuing to experience conflict, as the religious identity/participation is too important to abandon ("Loyalty"). This study has focused on the first path, "Exit", but the other two paths would certainly be interesting points of study and have consequences for our understanding of religious change and participation. Studies of these alternate paths could ask such questions as: Do some religionists remain in a liminal phase between belonging and disaffiliating? If so, why? What are the reasons for a conflicted religionist remaining in a church with which they conflict? Why do some religionists experience conflict and have no measurable decline in religious participation? Another vein of future study could incorporate in-depth interviews in order to better capture the cognitive dissonance that comes from being a conflicted religionist - how does one resolve political-religious conflict? Finally, future studies might consider other salient social issues on which individuals may conflict, such as environmentalism, cohabitation, pre-martial sex, and marijuana legalization, to name a few.

As political culture inevitably changes, and socio-political attitudes necessarily change along with it, there will continue to be opportunity for conflict between religionists and churches. In order to fully understand the political and religious landscape of the United States and elsewhere, social scientists must continue to study this evolving phenomenon. 


\section{References}

Adamczyk, Amy and Cassady Pitt. 2009. "Shaping attitudes about homosexuality: The role of religion and cultural context." Social Science Research 38:338-351.

Bader, Christopher D., F. Carson Mencken, and Paul Froese. 2007. "American Piety 2005: Content and Methods of the Baylor Religion Survey." Journal for the Scientific Study of Religion 46:447-463.

Baunach, D. M. 2012. "Changing Same-Sex Marriage Attitudes in America from 1988 Through 2010." Public Opinion Quarterly 76:364-378.

Bolzendahl, Catherine and Clem Brooks. 2005. "Polarization, Secularization, or Differences as Usual? The Denominational Cleavage in U.S. Social Attitudes Since the 1970s." The Sociological Quarterly 46:47-78.

Chaves, Mark and Philip S Gorski. 2001. "Religious pluralism and religious participation." Annual Review of Sociology 27:261-281.

Djupe, Paul A. 2011. "Political Pluralism and the Information Search: Determinants of Group Opinionation." Political Research Quarterly 64:68-81.

Djupe, Paul A and Christopher P Gilbert. 2008. "Politics and church: Byproduct or central mission?" Journal for the Scientific Study of Religion 47:45-62.

Djupe, Paul A and Andrew R Lewis. 2015. "Solidarity and Discord of Pluralism: How the Social Context Affects Interest Group Learning and Belonging." American Politics Research 43:394-424.

Djupe, Paul A., Jacob R. Neiheisel, and Kimberly H. Conger. 2018a. "Are the Politics of the Christian Right Linked to State Rates of the Non-Religious? The Importance of Salient Controversy." Political Research Quarterly 71:910-922.

Djupe, Paul A, Jacob R Neiheisel, and Anand E Sokhey. 2018b. "Reconsidering the Role of Politics in Leaving Religion: The Importance of Affiliation." American Journal of Political Science 62:161-175.

Domke, David Scott. and Kevin M. Coe. 2008. The God strategy : how religion became a political weapon in America. Oxford University Press.

Dumouchel, William H and Greg J Duncan. 1983. "Using Sample Survey Weights in Multiple Regression Analyses of Stratified Samples." Journal of the American Statistical Association 78:535-543.

Ellison, Christopher G., Samuel Echevarria, and Brad Smith. 2005. "Religion and Abortion Attitudes Among U.S. Hispanics: Findings from the 1990 Latino National Political Survey*." Social Science Quarterly 86:192-208.

Evans, John H. 2002. "Polarization in Abortion Attitudes in U.S. Religious Traditions, 1972-1998." Sociological Forum 17:1972-1998. 
Gay, David A., John P. Lynxwiler, and Patrick Smith. 2015. "Religiosity, Spirituality, and Attitudes Toward Same-Sex Marriage." SAGE Open 5:215824401560252.

Hirschman, Albert O. 1970. Exit, voice, and loyalty : responses to decline in firms, organizations, and states. Cambridge, Mass.: Harvard University Press.

Hoffmann, John P and Sherrie Mills Johnson. 2005. "Attitudes Toward Abortion Among Religious Traditions in the United States: Change or Continuity?" Sociology of Religion 66:161-182.

Hout, Michael and Claude S Fischer. 2002. "Why More Americans Have No Religious Preference: Politics and Generations." Source American Sociological Review 67:165-190.

Hout, Michael and Claude S Fischer. 2014. "Explaining Why More Americans Have No Religious Preference: Political Backlash and Generational Succession." Sociological Science 1:423-447.

Iacus, Stefano, Gary King, and Giuseppe Porro. 2009. "CEM: Software for Coarsened Exact Matching." Journal of Statistical Software 30.

Jelen, Ted G. and Clyde Wilcox. 2003. "Causes and Consequences of Public Attitudes Toward Abortion: A Review and Research Agenda." Political Research Quarterly 56:489-500.

Lim, Chaeyoon and Robert D Putnam. 2010. "Religion, Social Networks, and Life Satisfaction." American Sociological Review 75:914-933.

Manza, Jeff and Clem Brooks. 1997. "The Religious Factor in U.S. Presidential Elections, 1960-1992." American Jounral of Sociology 103:38-81.

Mize, Trenton D., Long Doan, and J. Scott Long. 2019. "A General Framework for Comparing Predictions and Marginal Effects across Models." Sociological Methodology pp. $1-38$.

Morgan, Stephen L. and Christopher Winship. 2014. Counterfactuals and Causal Inference: Methods and Principles for Social Research. Analytical Methods for Social Research. Cambridge University Press, 2 edition.

Norris, Pippa. and Ronald. Inglehart. 2004. Sacred and Secular: Religion and Politics Worldwide. Cambridge: Cambridge University Press.

Ohlander, Julianne, Jeanne Batalova, and Judith Treas. 2005. "Explaining educational influences on attitudes toward homosexual relations." Social Science Research 34:781-799.

Olson, Laura R., Wendy Cadge, and James T. Harrison. 2006. "Religion and Public Opinion about Same-Sex Marriage*." Social Science Quarterly 87:340-360.

Patrikios, Stratos. 2008. "American Republican Religion? Disentangling the Casual Link Between Religion and Politics in the US." Political Behavior 30:369-389. 
Phelan, Jo, Bruce G Link, Ann Stueve, and Robert E Moore. 1995. "Education, Social Liberalism, and Economic Conservatism: Attitudes Toward Homeless." American Sociological Review 60:126-140.

Powell, Brian, Catherine Bozendahl, Claudia Geist, and Lala Carr Steelman. 2010. Counted Out: Same-Sex Relations and Americans' Definitions of Family. New York: Russell Sage Foundation.

Schnabel, Landon. 2016. "Gender and homosexuality attitudes across religious groups from the 1970s to 2014: Similarity, distinction, and adaptation." Social Science Research 55:3147.

Schnabel, Landon and Sean Bock. 2017. "The Persistent and Exceptional Intensity of American Religion." Sociological Science pp. 686-700.

Schnabel, Landon and Sean Bock. 2018. "The continuing persistence of intense religion in the United States." Sociological Science 5:711-721.

Schoon, Ingrid, Helen Cheng, Catharine R Gale, G David Batty, and Ian J Deary. 2009. "Social status, cognitive ability, and educational attainment as predictors of liberal social attitudes and political trust." Intelligence 38:144-150.

Schwadel, Philip. 2010. "Period and Cohort Effects on Religious Nonaffiliation and Religious Disaffiliation: A." Technical Report 2.

Schwadel, Philip. 2011. "The Effects of Education on Americans' Religious Practices, Beliefs, and Affiliations." Review of Religious Research 53:161-182.

Sherkat, Darren E., Kylan Mattias de Vries, and Stacia Creek. 2010. "Race, Religion, and Opposition to Same-Sex Marriage." Social Science Quarterly 91:80-98.

Smith, Christian, Kyle Longest, Jonathan Hill, and Kari Christofferson. 2014. Young Catholic America : Emerging Adults In, Out of, and Gone from the Church. Oxford: Oxford University Press.

Voas, David and Mark Chaves. 2016. "Is the United States a Counterexample to the Secularization Thesis?" American Journal of Sociology 121:1-40.

Winship, Christopher and Larry Radbill. 1994. "Sampling Weights and Regression Analysis." Sociological Methods \& Research 23:230-257.

Wuthnow, Robert. 1988. The Restructuring of American Religion : Society and Faith Since World War II. Princeton, N.J.: Princeton University Press. 


\section{Appendix A. Creation of dependent variables}

Table A1: Weighted distribution of original survey items used to create dependent variables

"By your best guess how would your current place of worship feel about each of the following? Homosexual behavior."

Forbids $\quad 44.14 \%$

Strongly discourages $\quad 23.38 \%$

Somewhat discourages $\quad 9.63 \%$

Encourages $\quad 0.24 \%$

Isn't concerned $\quad 9.89 \%$

Don't know $\quad 12.72 \%$

"Please indicate your level of agreement with the following statements about homosexuals: Homosexuals should be allowed to marry."

Strongly disagree $\quad 36 \%$

Disagree $\quad 19.91 \%$

Agree $\quad 13.62 \%$

Strongly agree $\quad 18.55 \%$

Undecided $\quad 11.93 \%$

"By your best guess, how would your current place of worship feel about each of the following behaviors? Abortion"

Forbids $\quad 51.98 \%$

Strongly discourages $\quad 25.01 \%$

Somewhat discourages $\quad 6.93 \%$

Encourages $\quad 0.7 \%$

Isn't concerned $\quad 4.6 \%$

Don't know $\quad 10.78 \%$

"How do you feel about the morality of the following: Abortion, if the family cannot afford the child?"

Always wrong $\quad 46.48 \%$

Almost always wrong $\quad 14.53 \%$

Only wrong sometimes $14.86 \%$

Not wrong at all $\quad 24.13 \%$ 


\section{Appendix B. Tables}

Table B1: Weighted descriptive statistics: Full sample

\begin{tabular}{|c|c|c|c|}
\hline & $\mathrm{N}$ & Mean & $\mathrm{SD}$ \\
\hline \multicolumn{4}{|l|}{ Conflicted religionists } \\
\hline Conflicted on Same-Sex Marriage & 920 & 0.25 & 0.44 \\
\hline Conflicted on Abortion & 1003 & 0.21 & 0.41 \\
\hline \multicolumn{4}{|l|}{ Church attendance measures } \\
\hline $\ln ($ Attendance frequency) & 1623 & 2.14 & 1.80 \\
\hline Lower attendance from age 12 & 1648 & 0.65 & 0.48 \\
\hline \multicolumn{4}{|l|}{ Political ideology } \\
\hline Conservative & 1595 & 0.45 & 0.50 \\
\hline Moderate & 1595 & 0.29 & 0.45 \\
\hline Liberal & 1595 & 0.26 & 0.44 \\
\hline \multicolumn{4}{|l|}{ Education } \\
\hline Low & 1613 & 0.37 & 0.48 \\
\hline Medium & 1613 & 0.38 & 0.48 \\
\hline High & 1613 & 0.26 & 0.44 \\
\hline \multicolumn{4}{|l|}{ Religious tradition } \\
\hline Evangelical Protestant & 1387 & 0.38 & 0.49 \\
\hline Black Protestant & 1387 & 0.06 & 0.23 \\
\hline Mainline Protestant & 1387 & 0.24 & 0.43 \\
\hline Catholic & 1387 & 0.26 & 0.44 \\
\hline Other & 1387 & 0.07 & 0.25 \\
\hline Age & 1648 & 47.35 & 16.82 \\
\hline $\mathrm{Age}^{2}$ & 1648 & 2525.11 & 1718.25 \\
\hline $\mathrm{Age}^{3}$ & 1648 & 147967.81 & 146532.59 \\
\hline \multicolumn{4}{|l|}{ Party ID } \\
\hline Republican & 1573 & 0.40 & 0.49 \\
\hline Independent & 1573 & 0.22 & 0.42 \\
\hline Democrat & 1573 & 0.38 & 0.49 \\
\hline Female & 1648 & 0.53 & 0.50 \\
\hline \multicolumn{4}{|l|}{ Urban/Rural } \\
\hline City & 1579 & 0.13 & 0.34 \\
\hline Suburbs & 1579 & 0.28 & 0.45 \\
\hline Small city or town & 1579 & 0.38 & 0.49 \\
\hline Rural & 1579 & 0.21 & 0.41 \\
\hline \multicolumn{4}{|l|}{ Region } \\
\hline East & 1648 & 0.22 & 0.41 \\
\hline Midwest & 1648 & 0.23 & 0.42 \\
\hline South & 1648 & 0.32 & 0.47 \\
\hline West & 1648 & 0.22 & 0.42 \\
\hline
\end{tabular}




\begin{tabular}{llll}
\hline White & 1606 & 0.85 & 0.36 \\
Very Religious & 1602 & 0.32 & 0.47 \\
\hline
\end{tabular}

Source: Baylor Religion Survey, Wave II (2007)

Table B2: Weighted descriptive statistics: Reduced samples

\begin{tabular}{|c|c|c|c|}
\hline & $\mathrm{N}$ & Mean & $\mathrm{SD}$ \\
\hline \multicolumn{4}{|l|}{ Same-sex marriage sample } \\
\hline \multicolumn{4}{|l|}{ Conflicted religionists } \\
\hline Conflicted on Same-Sex Marriage & 48 & 0.27 & 0.45 \\
\hline Conflicted on Abortion & 0 & & 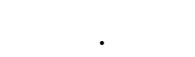 \\
\hline \multicolumn{4}{|l|}{ Church attendance measures } \\
\hline $\ln$ (Attendance frequency) & 48 & 2.21 & 1.67 \\
\hline Lower attendance from age 12 & 48 & 0.60 & 0.50 \\
\hline \multicolumn{4}{|l|}{ Political ideology } \\
\hline Conservative & 48 & 0.54 & 0.50 \\
\hline Moderate & 48 & 0.28 & 0.45 \\
\hline Liberal & 48 & 0.18 & 0.39 \\
\hline \multicolumn{4}{|l|}{ Education } \\
\hline Low & 48 & 0.36 & 0.49 \\
\hline Medium & 48 & 0.39 & 0.49 \\
\hline High & 48 & 0.24 & 0.43 \\
\hline \multicolumn{4}{|l|}{ Religious tradition } \\
\hline Evangelical Protestant & 48 & 0.31 & 0.47 \\
\hline Black Protestant & 48 & 0.15 & 0.36 \\
\hline Mainline Protestant & 48 & 0.40 & 0.49 \\
\hline Catholic & 48 & 0.06 & 0.24 \\
\hline Other & 48 & 0.08 & 0.28 \\
\hline Age & 48 & 49.37 & 16.28 \\
\hline $\mathrm{Age}^{2}$ & 48 & 2696.42 & 1660.91 \\
\hline $\operatorname{Age}^{3}$ & 48 & 159205.40 & 139484.02 \\
\hline \multicolumn{4}{|l|}{ Party ID } \\
\hline Republican & 46 & 0.49 & 0.51 \\
\hline Independent & 46 & 0.22 & 0.42 \\
\hline Democrat & 46 & 0.29 & 0.46 \\
\hline Female & 48 & 0.37 & 0.49 \\
\hline \multicolumn{4}{|l|}{ Urban/Rural } \\
\hline City & 48 & 0.20 & 0.40 \\
\hline Suburbs & 48 & 0.09 & 0.29 \\
\hline Small city or town & 48 & 0.38 & 0.49 \\
\hline Rural & 48 & 0.34 & 0.48 \\
\hline \multicolumn{4}{|l|}{ Region } \\
\hline East & 48 & 0.21 & 0.41 \\
\hline
\end{tabular}




\begin{tabular}{|c|c|c|c|}
\hline Midwest & 48 & 0.12 & 0.33 \\
\hline South & 48 & 0.47 & 0.50 \\
\hline West & 48 & 0.19 & 0.40 \\
\hline White & 48 & 0.73 & 0.45 \\
\hline Very Religious & 48 & 0.41 & 0.50 \\
\hline \multicolumn{4}{|l|}{ Abortion sample } \\
\hline \multicolumn{4}{|l|}{ Conflicted religionists } \\
\hline Conflicted on Same-Sex Marriage & 788 & 0.24 & 0.43 \\
\hline Conflicted on Abortion & 894 & 0.19 & 0.39 \\
\hline \multicolumn{4}{|l|}{ Church attendance measures } \\
\hline $\ln$ (Attendance frequency) & 893 & 3.01 & 1.51 \\
\hline Lower attendance from age 12 & 894 & 0.51 & 0.50 \\
\hline \multicolumn{4}{|l|}{ Political ideology } \\
\hline Conservative & 894 & 0.58 & 0.49 \\
\hline Moderate & 894 & 0.27 & 0.45 \\
\hline Liberal & 894 & 0.15 & 0.36 \\
\hline \multicolumn{4}{|l|}{ Education } \\
\hline Low & 894 & 0.36 & 0.48 \\
\hline Medium & 894 & 0.40 & 0.49 \\
\hline High & 894 & 0.24 & 0.42 \\
\hline \multicolumn{4}{|l|}{ Religious tradition } \\
\hline Evangelical Protestant & 894 & 0.43 & 0.50 \\
\hline Black Protestant & 894 & 0.05 & 0.22 \\
\hline Mainline Protestant & 894 & 0.18 & 0.39 \\
\hline Catholic & 894 & 0.29 & 0.45 \\
\hline Other & 894 & 0.05 & 0.22 \\
\hline Age & 894 & 47.91 & 16.61 \\
\hline $\mathrm{Age}^{2}$ & 894 & 2571.34 & 1708.04 \\
\hline $\mathrm{Age}^{3}$ & 894 & 151054.84 & 146508.46 \\
\hline \multicolumn{4}{|l|}{ Party ID } \\
\hline Republican & 877 & 0.51 & 0.50 \\
\hline Independent & 877 & 0.19 & 0.39 \\
\hline Democrat & 877 & 0.30 & 0.46 \\
\hline Female & 894 & 0.57 & 0.49 \\
\hline \multicolumn{4}{|l|}{ Urban/Rural } \\
\hline City & 894 & 0.11 & 0.32 \\
\hline Suburbs & 894 & 0.27 & 0.45 \\
\hline Small city or town & 894 & 0.40 & 0.49 \\
\hline Rural & 894 & 0.22 & 0.41 \\
\hline \multicolumn{4}{|l|}{ Region } \\
\hline East & 894 & 0.20 & 0.40 \\
\hline Midwest & 894 & 0.26 & 0.44 \\
\hline South & 894 & 0.35 & 0.48 \\
\hline
\end{tabular}




\begin{tabular}{|c|c|c|c|}
\hline West & 894 & 0.19 & 0.39 \\
\hline White & 889 & 0.86 & 0.35 \\
\hline Very Religious & 894 & 0.45 & 0.50 \\
\hline \multicolumn{4}{|l|}{ Total } \\
\hline \multicolumn{4}{|l|}{ Conflicted religionists } \\
\hline Conflicted on Same-Sex Marriage & 836 & 0.25 & 0.43 \\
\hline Conflicted on Abortion & 894 & 0.19 & 0.39 \\
\hline \multicolumn{4}{|l|}{ Church attendance measures } \\
\hline $\ln ($ Attendance frequency) & 941 & 2.97 & 1.53 \\
\hline Lower attendance from age 12 & 942 & 0.51 & 0.50 \\
\hline \multicolumn{4}{|l|}{ Political ideology } \\
\hline Conservative & 942 & 0.57 & 0.49 \\
\hline Moderate & 942 & 0.27 & 0.45 \\
\hline Liberal & 942 & 0.15 & 0.36 \\
\hline \multicolumn{4}{|l|}{ Education } \\
\hline Low & 942 & 0.36 & 0.48 \\
\hline Medium & 942 & 0.40 & 0.49 \\
\hline High & 942 & 0.24 & 0.42 \\
\hline \multicolumn{4}{|l|}{ Religious tradition } \\
\hline Evangelical Protestant & 942 & 0.42 & 0.49 \\
\hline Black Protestant & 942 & 0.06 & 0.23 \\
\hline Mainline Protestant & 942 & 0.19 & 0.40 \\
\hline Catholic & 942 & 0.28 & 0.45 \\
\hline Other & 942 & 0.05 & 0.23 \\
\hline Age & 942 & 47.99 & 16.59 \\
\hline $\mathrm{Age}^{2}$ & 942 & 2578.12 & 1704.84 \\
\hline $\mathrm{Age}^{3}$ & 942 & 151497.10 & 146072.18 \\
\hline \multicolumn{4}{|l|}{ Party ID } \\
\hline Republican & 923 & 0.51 & 0.50 \\
\hline Independent & 923 & 0.19 & 0.39 \\
\hline Democrat & 923 & 0.30 & 0.46 \\
\hline Female & 942 & 0.56 & 0.50 \\
\hline \multicolumn{4}{|l|}{ Urban/Rural } \\
\hline City & 942 & 0.12 & 0.32 \\
\hline Suburbs & 942 & 0.26 & 0.44 \\
\hline Small city or town & 942 & 0.39 & 0.49 \\
\hline Rural & 942 & 0.23 & 0.42 \\
\hline \multicolumn{4}{|l|}{ Region } \\
\hline East & 942 & 0.20 & 0.40 \\
\hline Midwest & 942 & 0.25 & 0.44 \\
\hline South & 942 & 0.36 & 0.48 \\
\hline West & 942 & 0.19 & 0.39 \\
\hline White & 937 & 0.85 & 0.36 \\
\hline
\end{tabular}




\begin{tabular}{lccc}
\hline Very Religious & 942 & 0.45 & 0.50 \\
\hline
\end{tabular}

Source: Baylor Religion Survey, Wave II (2007)

Table B3: Logistic regression predicting conflicted religionist

\begin{tabular}{|c|c|c|}
\hline & Same-sex marriage & Abortion \\
\hline Conservative & Ref & Ref \\
\hline Moderate & $\begin{array}{c}0.925^{* * *} \\
(0.254)\end{array}$ & $\begin{array}{c}0.319 \\
(0.268)\end{array}$ \\
\hline Liberal & $\begin{array}{c}1.992^{* * *} \\
(0.307)\end{array}$ & $\begin{array}{c}1.514^{* * *} \\
(0.309)\end{array}$ \\
\hline Low & Ref & Ref \\
\hline Medium & $\begin{array}{c}0.447 \\
(0.242)\end{array}$ & $\begin{array}{c}0.171 \\
(0.253)\end{array}$ \\
\hline High & $\begin{array}{c}0.302 \\
(0.258)\end{array}$ & $\begin{array}{c}0.205 \\
(0.261)\end{array}$ \\
\hline Age & $\begin{array}{c}-0.086 \\
(0.136)\end{array}$ & $\begin{array}{l}0.399^{* *} \\
(0.143)\end{array}$ \\
\hline $\mathrm{Age}^{2}$ & $\begin{array}{c}0.002 \\
(0.003)\end{array}$ & $\begin{array}{c}-0.008^{* *} \\
(0.003)\end{array}$ \\
\hline $\mathrm{Age}^{3}$ & $\begin{array}{c}-0.000 \\
(0.000)\end{array}$ & $\begin{array}{l}0.000^{* *} \\
(0.000)\end{array}$ \\
\hline Evangelical Protestant & Ref & Ref \\
\hline Black Protestant & $\begin{array}{c}-0.925 \\
(0.566)\end{array}$ & $\begin{array}{c}2.016^{* * *} \\
(0.572)\end{array}$ \\
\hline Mainline Protestant & $\begin{array}{c}0.660^{*} \\
(0.275)\end{array}$ & $\begin{array}{c}1.299^{* * *} \\
(0.285)\end{array}$ \\
\hline Catholic & $\begin{array}{l}0.676^{* *} \\
(0.246)\end{array}$ & $\begin{array}{c}0.497 \\
(0.277)\end{array}$ \\
\hline Other & $\begin{array}{c}0.146 \\
(0.461)\end{array}$ & $\begin{array}{l}1.302^{* *} \\
(0.422)\end{array}$ \\
\hline Republican & Ref & Ref \\
\hline
\end{tabular}




\begin{tabular}{|c|c|c|}
\hline Independent & $\begin{array}{c}0.233 \\
(0.287)\end{array}$ & $\begin{array}{c}0.300 \\
(0.305)\end{array}$ \\
\hline Democrat & $\begin{array}{l}0.558^{*} \\
(0.271)\end{array}$ & $\begin{array}{c}0.438 \\
(0.283)\end{array}$ \\
\hline Male & Ref & Ref \\
\hline Female & $\begin{array}{c}0.050 \\
(0.196)\end{array}$ & $\begin{array}{l}-0.008 \\
(0.199)\end{array}$ \\
\hline A large city & Ref & Ref \\
\hline A suburb near a large city & $\begin{array}{l}-0.487 \\
(0.303)\end{array}$ & $\begin{array}{c}0.016 \\
(0.323)\end{array}$ \\
\hline A small city or town & $\begin{array}{l}-0.480 \\
(0.293)\end{array}$ & $\begin{array}{l}-0.004 \\
(0.311)\end{array}$ \\
\hline A rural area & $\begin{array}{l}-0.264 \\
(0.334)\end{array}$ & $\begin{array}{l}-0.092 \\
(0.363)\end{array}$ \\
\hline East & Ref & Ref \\
\hline Mid-West & $\begin{array}{c}0.074 \\
(0.270)\end{array}$ & $\begin{array}{l}-0.039 \\
(0.270)\end{array}$ \\
\hline South & $\begin{array}{c}-0.012 \\
(0.277)\end{array}$ & $\begin{array}{l}-0.290 \\
(0.284)\end{array}$ \\
\hline West & $\begin{array}{c}0.139 \\
(0.300)\end{array}$ & $\begin{array}{l}-0.155 \\
(0.299)\end{array}$ \\
\hline Non-White & Ref & Ref \\
\hline White & $\begin{array}{l}-0.166 \\
(0.279)\end{array}$ & $\begin{array}{l}0.859^{*} \\
(0.348)\end{array}$ \\
\hline Not very religious & Ref & Ref \\
\hline Very religious & $\begin{array}{c}-0.574^{* *} \\
(0.208)\end{array}$ & $\begin{array}{r}-1.166^{* * *} \\
(0.231)\end{array}$ \\
\hline Constant & $\begin{array}{l}-0.395 \\
(2.201)\end{array}$ & $\begin{array}{r}-9.336^{* * *} \\
(2.437)\end{array}$ \\
\hline $\begin{array}{l}\text { Pseudo } R^{2} \\
B I C\end{array}$ & $\begin{array}{c}0.214 \\
881.873\end{array}$ & $\begin{array}{c}0.214 \\
858.016\end{array}$ \\
\hline
\end{tabular}




\begin{tabular}{lll}
\hline Observations & 815 & 872 \\
\hline
\end{tabular}

Standard errors in parentheses

${ }^{*} p<0.05,{ }^{* *} p<0.01,{ }^{* * *} p<0.001$

Table B4: OLS regression predicting church attendance frequency

\begin{tabular}{|c|c|c|c|c|c|c|}
\hline & \multicolumn{3}{|c|}{ Same-sex marriage } & \multicolumn{3}{|c|}{ Abortion } \\
\hline & Baseline & Full & CEM & Baseline & Full & CEM \\
\hline 0 & Ref & Ref & Ref & Ref & Ref & Ref \\
\hline 1 & $\begin{array}{c}-0.878^{* * *} \\
(0.112)\end{array}$ & $\begin{array}{c}-0.335^{* *} \\
(0.114)\end{array}$ & $\begin{array}{c}-0.728^{* *} \\
(0.242)\end{array}$ & $\begin{array}{c}-1.071^{* * *} \\
(0.111)\end{array}$ & $\begin{array}{c}-0.491^{* * *} \\
(0.113)\end{array}$ & $\begin{array}{c}-1.006^{* * *} \\
(0.269)\end{array}$ \\
\hline Conservative & & Ref & & & Ref & \\
\hline Moderate & & $\begin{array}{l}-0.024 \\
(0.123)\end{array}$ & & & $\begin{array}{c}0.023 \\
(0.114)\end{array}$ & \\
\hline Liberal & & $\begin{array}{l}-0.121 \\
(0.165)\end{array}$ & & & $\begin{array}{l}-0.103 \\
(0.150)\end{array}$ & \\
\hline Low & & Ref & & & Ref & \\
\hline Medium & & $\begin{array}{c}0.173 \\
(0.110)\end{array}$ & & & $\begin{array}{c}0.081 \\
(0.105)\end{array}$ & \\
\hline High & & $\begin{array}{l}0.302^{* *} \\
(0.117)\end{array}$ & & & $\begin{array}{l}0.223^{*} \\
(0.110)\end{array}$ & \\
\hline Age & & $\begin{array}{l}-0.157^{*} \\
(0.063)\end{array}$ & & & $\begin{array}{l}-0.112 \\
(0.058)\end{array}$ & \\
\hline $\mathrm{Age}^{2}$ & & $\begin{array}{l}0.003^{*} \\
(0.001)\end{array}$ & & & $\begin{array}{c}0.002 \\
(0.001)\end{array}$ & \\
\hline $\mathrm{Age}^{3}$ & & $\begin{array}{l}-0.000^{*} \\
(0.000)\end{array}$ & & & $\begin{array}{l}-0.000 \\
(0.000)\end{array}$ & \\
\hline Evangelical Protestant & & Ref & & & Ref & \\
\hline Black Protestant & & $\begin{array}{c}0.006 \\
(0.258)\end{array}$ & & & $\begin{array}{c}0.409 \\
(0.262)\end{array}$ & \\
\hline Mainline Protestant & & $\begin{array}{c}-0.467^{* * *} \\
(0.129)\end{array}$ & & & $\begin{array}{c}-0.320^{* *} \\
(0.123)\end{array}$ & \\
\hline Catholic & & $-0.252^{*}$ & & & -0.190 & \\
\hline
\end{tabular}




\begin{tabular}{|c|c|c|}
\hline & $(0.115)$ & $(0.108)$ \\
\hline Other & $\begin{array}{l}-0.100 \\
(0.206)\end{array}$ & $\begin{array}{c}0.093 \\
(0.189)\end{array}$ \\
\hline Republican & Ref & Ref \\
\hline Independent & $\begin{array}{l}-0.088 \\
(0.133)\end{array}$ & $\begin{array}{l}-0.155 \\
(0.124)\end{array}$ \\
\hline Democrat & $\begin{array}{c}-0.037 \\
(0.134)\end{array}$ & $\begin{array}{l}-0.162 \\
(0.124)\end{array}$ \\
\hline Male & Ref & Ref \\
\hline Female & $\begin{array}{c}0.132 \\
(0.091)\end{array}$ & $\begin{array}{c}0.131 \\
(0.086)\end{array}$ \\
\hline A large city & Ref & Ref \\
\hline A suburb near a large city & $\begin{array}{c}0.057 \\
(0.146)\end{array}$ & $\begin{array}{c}0.044 \\
(0.142)\end{array}$ \\
\hline A small city or town & $\begin{array}{c}0.086 \\
(0.142)\end{array}$ & $\begin{array}{c}0.079 \\
(0.137)\end{array}$ \\
\hline A rural area & $\begin{array}{c}0.167 \\
(0.158)\end{array}$ & $\begin{array}{c}0.182 \\
(0.153)\end{array}$ \\
\hline East & Ref & Ref \\
\hline Mid-West & $\begin{array}{c}0.318^{*} \\
(0.131)\end{array}$ & $\begin{array}{l}0.338^{* *} \\
(0.124)\end{array}$ \\
\hline South & $\begin{array}{c}0.106 \\
(0.130)\end{array}$ & $\begin{array}{c}0.184 \\
(0.123)\end{array}$ \\
\hline West & $\begin{array}{c}-0.223 \\
(0.144)\end{array}$ & $\begin{array}{c}-0.208 \\
(0.134)\end{array}$ \\
\hline Non-White & Ref & Ref \\
\hline White & $\begin{array}{l}-0.271 \\
(0.142)\end{array}$ & $\begin{array}{c}-0.160 \\
(0.137)\end{array}$ \\
\hline Not very religious & Ref & Ref \\
\hline Very religious & $1.477^{* * *}$ & $1.406^{* * *}$ \\
\hline
\end{tabular}




\begin{tabular}{lcccccc}
\hline & & $(0.096)$ & & & $(0.092)$ \\
Constant & $3.237^{* * *}$ & $5.025^{* * *}$ & $3.174^{* * *}$ & $3.203^{* * *}$ & $4.350^{* * *}$ & $3.129^{* * *}$ \\
& $(0.057)$ & $(1.044)$ & $(0.144)$ & $(0.053)$ & $(0.963)$ & $(0.183)$ \\
\hline$R^{2}$ & 0.063 & 0.358 & 0.051 & 0.087 & 0.372 & 0.118 \\
$B I C$ & 3311.844 & 2786.689 & 748.974 & 3570.125 & 2936.504 & 416.550 \\
Observations & 910 & 814 & 204 & 991 & 871 & 118 \\
\hline
\end{tabular}

Standard errors in parentheses

${ }^{*} p<0.05,{ }^{* *} p<0.01,{ }^{* * *} p<0.001$

Note: the number of cases in the CEM models indicates the number of successfully matched cases.

Table B5: Logistic regression predicting decreased church attendance since age 12

\begin{tabular}{|c|c|c|c|c|c|c|}
\hline & \multicolumn{3}{|c|}{ Same-sex marriage } & \multicolumn{3}{|c|}{ Abortion } \\
\hline & Baseline & Full & CEM & Baseline & Full & CEM \\
\hline 0 & Ref & Ref & Ref & Ref & Ref & Ref \\
\hline 1 & $\begin{array}{c}0.677^{* * *} \\
(0.155)\end{array}$ & $\begin{array}{c}0.348 \\
(0.202)\end{array}$ & $\begin{array}{c}0.762^{*} \\
(0.340)\end{array}$ & $\begin{array}{c}0.960^{* * *} \\
(0.162)\end{array}$ & $\begin{array}{l}0.573^{* *} \\
(0.211)\end{array}$ & $\begin{array}{l}1.134^{*} \\
(0.462)\end{array}$ \\
\hline Conservative & & Ref & & & Ref & \\
\hline Moderate & & $\begin{array}{c}0.079 \\
(0.217)\end{array}$ & & & $\begin{array}{c}-0.052 \\
(0.205)\end{array}$ & \\
\hline Liberal & & $\begin{array}{c}0.023 \\
(0.292)\end{array}$ & & & $\begin{array}{c}0.029 \\
(0.273)\end{array}$ & \\
\hline Low & & Ref & & & Ref & \\
\hline Medium & & $\begin{array}{c}-0.021 \\
(0.194)\end{array}$ & & & $\begin{array}{c}0.166 \\
(0.189)\end{array}$ & \\
\hline High & & $\begin{array}{c}-0.199 \\
(0.205)\end{array}$ & & & $\begin{array}{c}-0.030 \\
(0.198)\end{array}$ & \\
\hline Age & & $\begin{array}{c}0.117 \\
(0.112)\end{array}$ & & & $\begin{array}{c}0.135 \\
(0.105)\end{array}$ & \\
\hline $\mathrm{Age}^{2}$ & & $\begin{array}{c}-0.002 \\
(0.002)\end{array}$ & & & $\begin{array}{c}-0.002 \\
(0.002)\end{array}$ & \\
\hline $\mathrm{Age}^{3}$ & & $\begin{array}{c}0.000 \\
(0.000)\end{array}$ & & & $\begin{array}{c}0.000 \\
(0.000)\end{array}$ & \\
\hline Evangelical Protestant & & Ref & & & Ref & \\
\hline
\end{tabular}




\begin{tabular}{|c|c|c|}
\hline Black Protestant & $\begin{array}{c}0.307 \\
(0.451)\end{array}$ & $\begin{array}{c}0.042 \\
(0.469)\end{array}$ \\
\hline Mainline Protestant & $\begin{array}{l}0.639^{* *} \\
(0.229)\end{array}$ & $\begin{array}{c}0.485^{*} \\
(0.222)\end{array}$ \\
\hline Catholic & $\begin{array}{c}0.353 \\
(0.202)\end{array}$ & $\begin{array}{c}0.298 \\
(0.194)\end{array}$ \\
\hline Other & $\begin{array}{l}-0.318 \\
(0.366)\end{array}$ & $\begin{array}{l}-0.473 \\
(0.344)\end{array}$ \\
\hline Republican & Ref & Ref \\
\hline Independent & $\begin{array}{c}0.137 \\
(0.235)\end{array}$ & $\begin{array}{c}0.376 \\
(0.224)\end{array}$ \\
\hline Democrat & $\begin{array}{c}-0.236 \\
(0.237)\end{array}$ & $\begin{array}{l}-0.009 \\
(0.225)\end{array}$ \\
\hline Male & Ref & Ref \\
\hline Female & $\begin{array}{c}-0.056 \\
(0.160)\end{array}$ & $\begin{array}{c}-0.030 \\
(0.155)\end{array}$ \\
\hline A large city & Ref & Ref \\
\hline A suburb near a large city & $\begin{array}{l}-0.116 \\
(0.258)\end{array}$ & $\begin{array}{l}-0.115 \\
(0.257)\end{array}$ \\
\hline A small city or town & $\begin{array}{l}-0.311 \\
(0.251)\end{array}$ & $\begin{array}{l}-0.218 \\
(0.248)\end{array}$ \\
\hline A rural area & $\begin{array}{l}-0.248 \\
(0.279)\end{array}$ & $\begin{array}{l}-0.198 \\
(0.276)\end{array}$ \\
\hline East & Ref & Ref \\
\hline Mid-West & $\begin{array}{l}-0.397 \\
(0.231)\end{array}$ & $\begin{array}{l}-0.436 \\
(0.224)\end{array}$ \\
\hline South & $\begin{array}{c}0.042 \\
(0.229)\end{array}$ & $\begin{array}{l}-0.041 \\
(0.222)\end{array}$ \\
\hline West & $\begin{array}{c}0.294 \\
(0.254)\end{array}$ & $\begin{array}{c}0.315 \\
(0.245)\end{array}$ \\
\hline Non-White & Ref & Ref \\
\hline
\end{tabular}




\begin{tabular}{|c|c|c|c|c|c|c|}
\hline White & & $\begin{array}{c}0.607^{*} \\
(0.250)\end{array}$ & & & $\begin{array}{c}0.570^{*} \\
(0.247)\end{array}$ & \\
\hline Not very religious & & Ref & & & Ref & \\
\hline Very religious & & $\begin{array}{c}-1.293^{* * *} \\
(0.166)\end{array}$ & & & $\begin{array}{c}-1.224^{* * *} \\
(0.163)\end{array}$ & \\
\hline Constant & $\begin{array}{c}-0.094 \\
(0.077)\end{array}$ & $\begin{array}{l}-1.810 \\
(1.849)\end{array}$ & $\begin{array}{c}0.206 \\
(0.207)\end{array}$ & $\begin{array}{l}-0.098 \\
(0.072)\end{array}$ & $\begin{array}{l}-2.348 \\
(1.735)\end{array}$ & $\begin{array}{c}0.358 \\
(0.276)\end{array}$ \\
\hline Pseudo $R^{2}$ & 0.015 & 0.113 & 0.022 & 0.027 & 0.120 & 0.049 \\
\hline$B I C$ & 1268.000 & 1162.622 & 277.579 & 1363.526 & 1224.933 & 149.764 \\
\hline Observations & 920 & 815 & 204 & 1003 & 872 & 118 \\
\hline
\end{tabular}

Standard errors in parentheses

${ }^{*} p<0.05,{ }^{* *} p<0.01,{ }^{* * *} p<0.001$

Note: the number of cases in the CEM models indicates the number of successfully matched cases. 


\section{Appendix C. Additional figures}


Figure C1: Predicted probabilities of experiencing conflict by all covariates

\section{Political orientation}

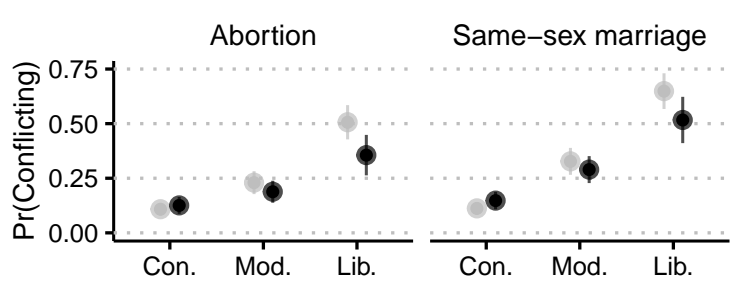

Age

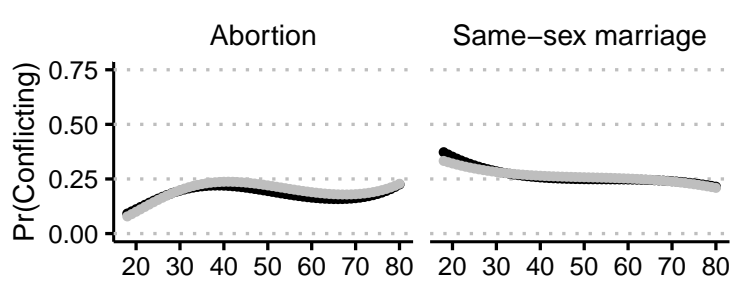

Race

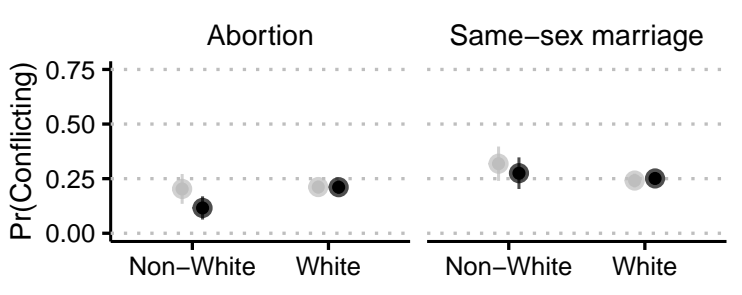

\section{Religiosity}

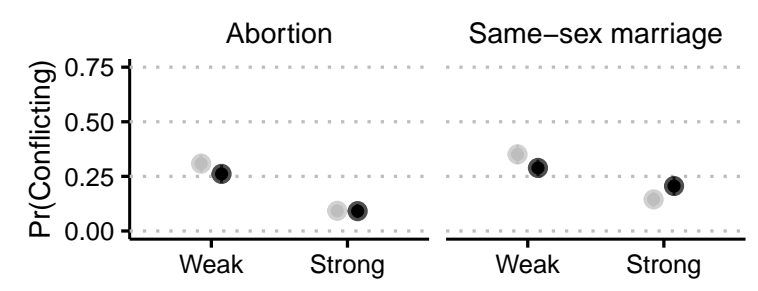

\section{Religious tradition}

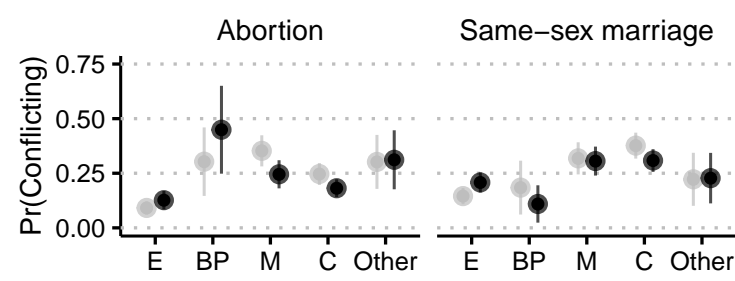

Gender

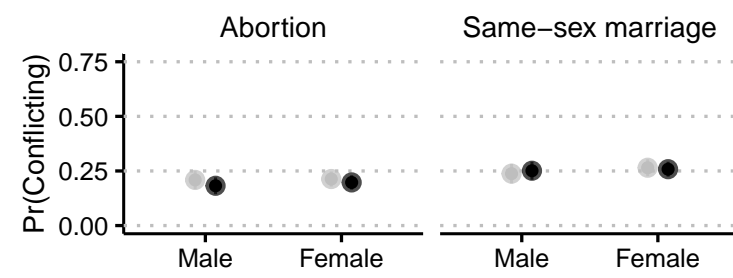

Geographic region

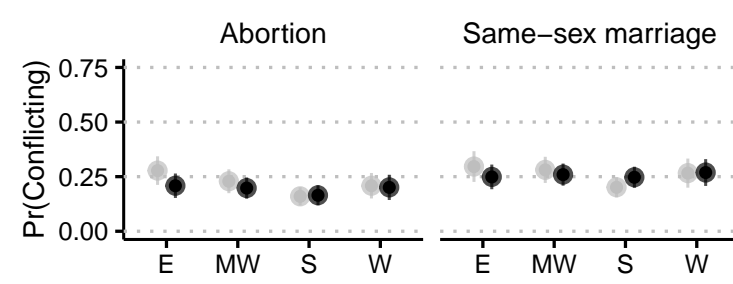

\section{Education Level}

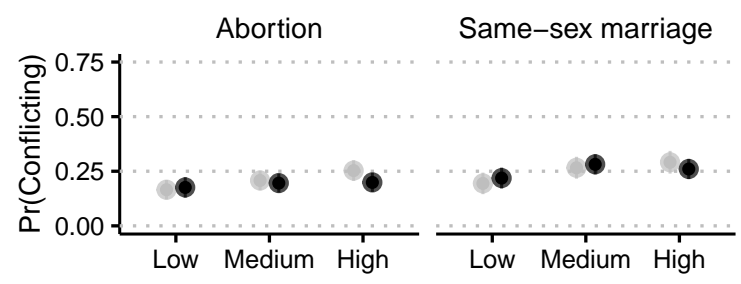

\section{Partisan identification}

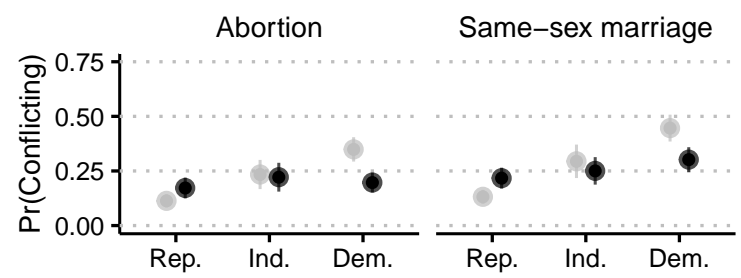

\section{Urban/rural}

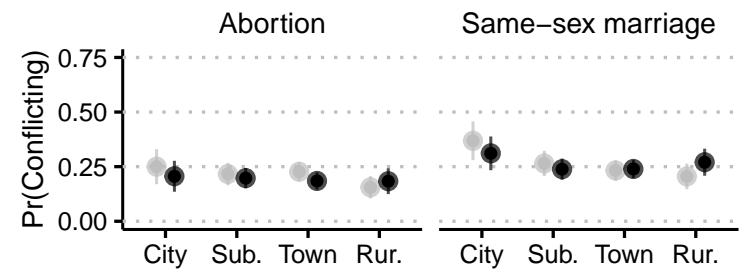

Model $\phi$ Unadjusted $\phi$ Adjusted 
Figure C2: Predicting church attendance frequency by conflictXcovariate interactions (with error bars)
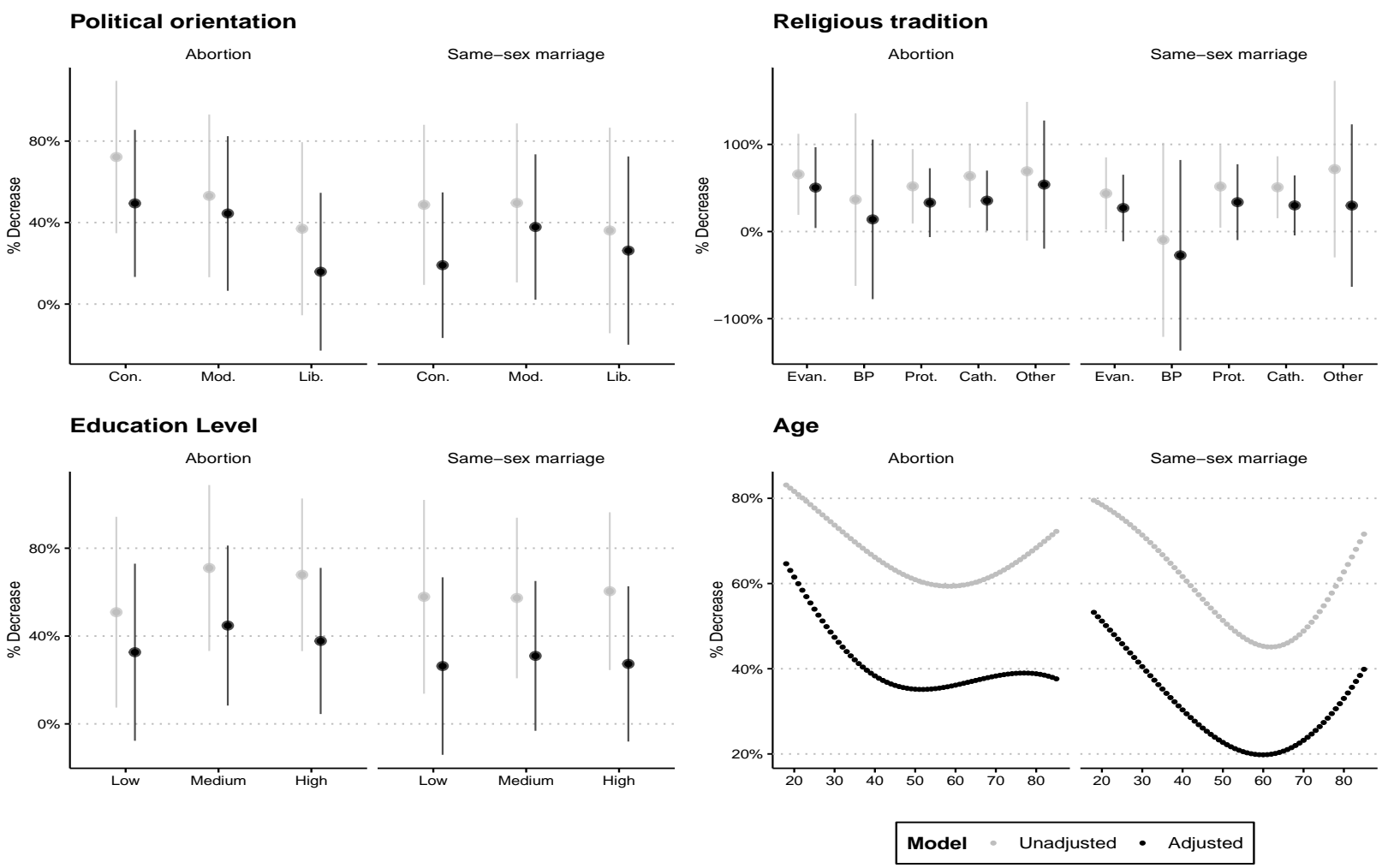


\section{Appendix D. Patterns for conflicted religionists in "lib- eral" churches}

Figure D1 displays frequencies of conflicted religionists who have more conservative views on abortion and same-sex marriage and their current church. While the there are too few cases among religionists conflicted on abortion, there are some interesting, yet not surprising, patterns for same-sex marriage. First, mainliners far and way have the highest number of conflicted religionists, which makes sense given the higher number of more liberal mainline churches. Religionists with high levels of education also appear to be much more likely to experience conflict. This is an interesting result, and I'm not sure what to make of it. It could be that religionists with higher levels of education are more likely to attend liberal churches, regardless of whether or not they agree with said church politically.

Figure D2 plots the mean logged church attendance frequency for conflicted religionists compared to non-conflicted religionists. There is a clear pattern for same-sex marriage, with conflicted religionists having a far lower average church attendance frequency. This finding

suggests that conflicted religion is associated with lower church attendance, regardless of the politics of the church or religionists. 
Figure D1: Frequency of second type of conflicted religionists by key covariates

\section{Political orientation}

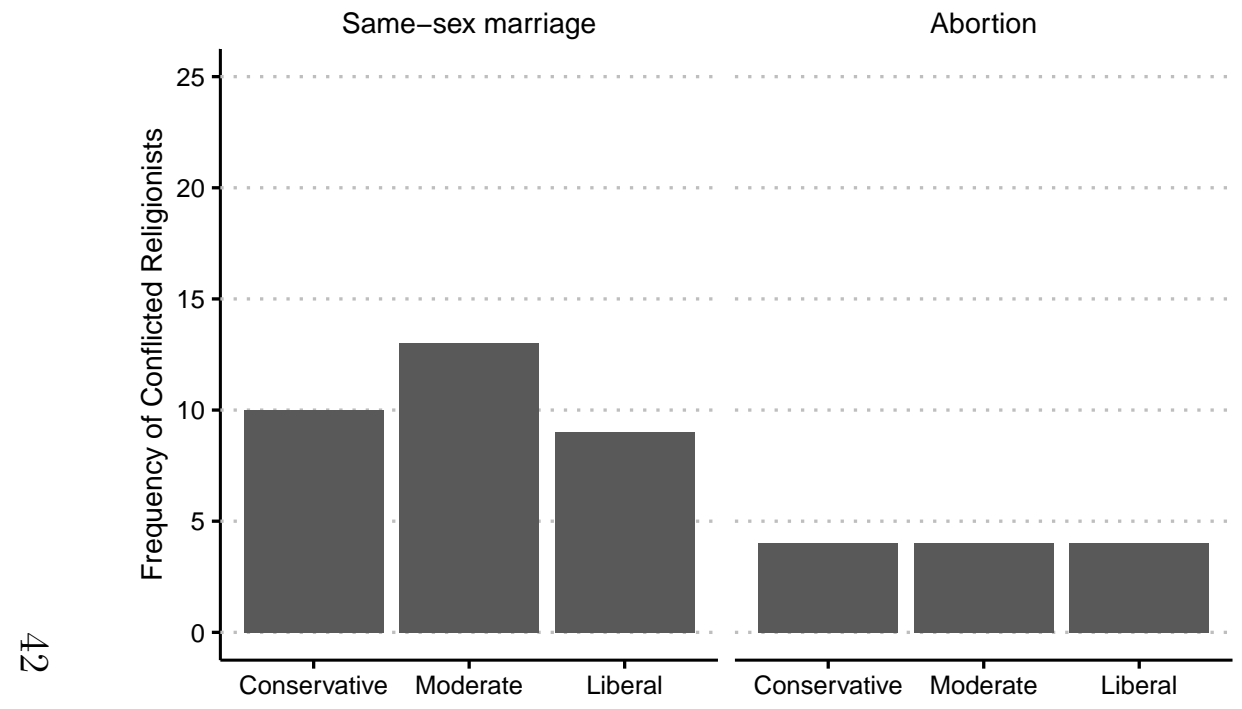

\section{Education}

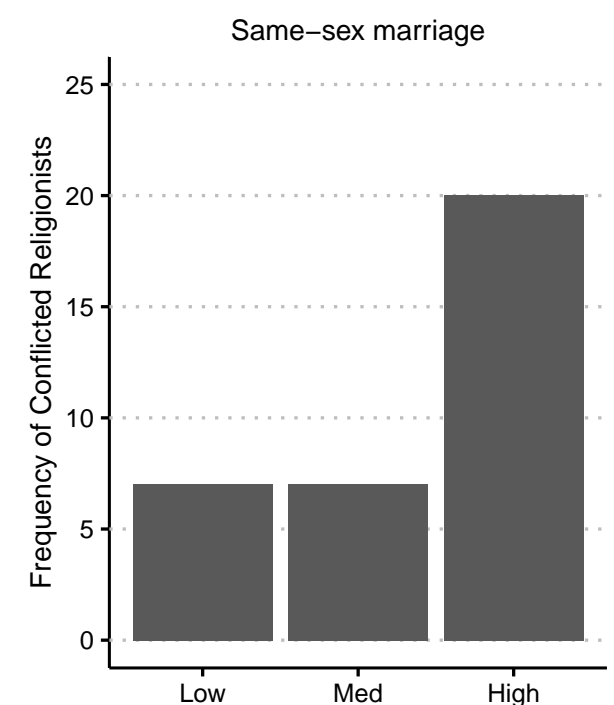

\section{Religious Tradition}

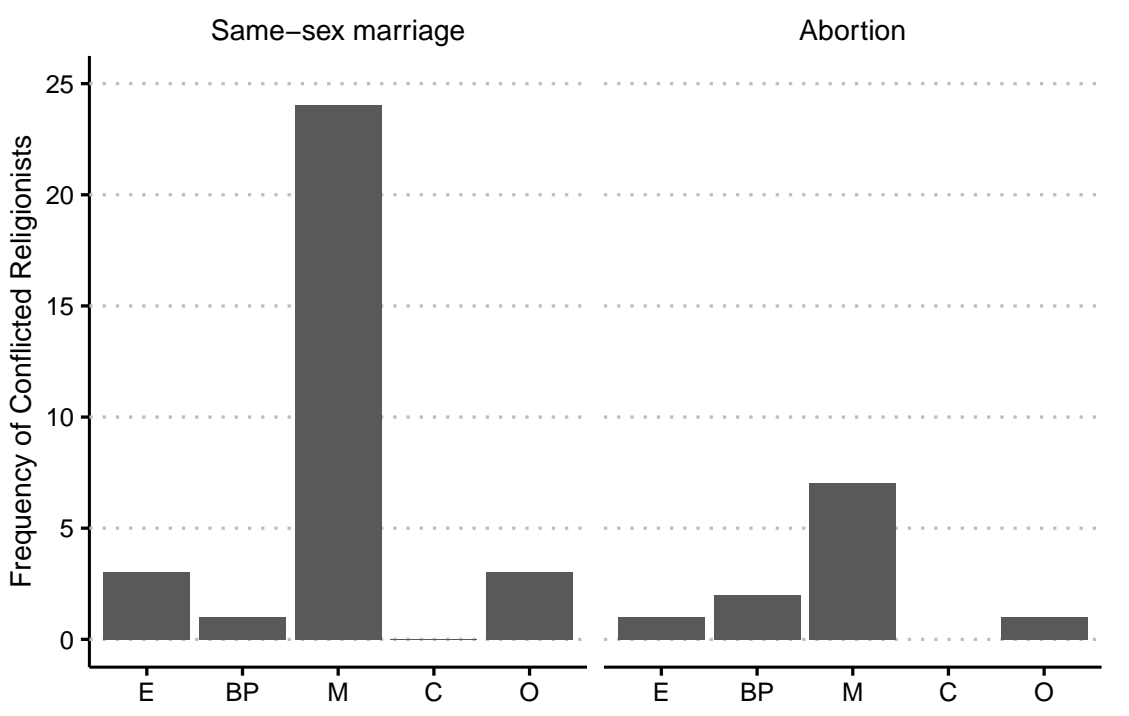

Age

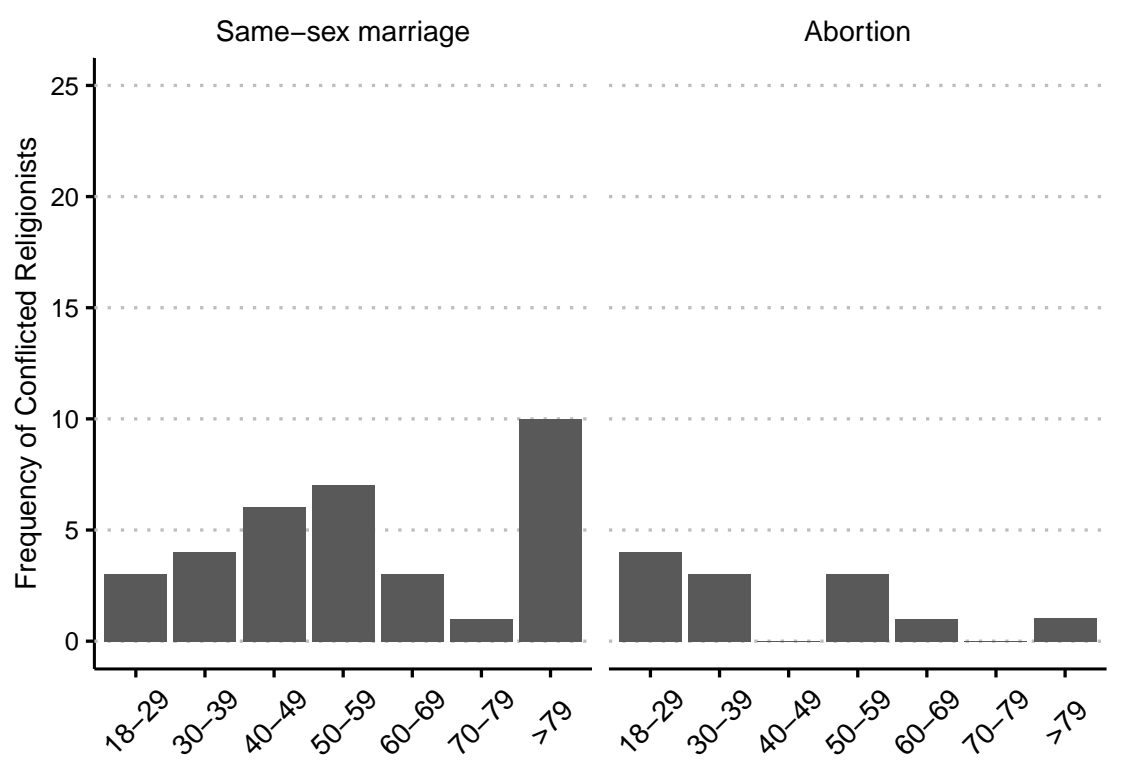


Figure D2: Church attendance levels for conflicted vs. non-conflicted religionists

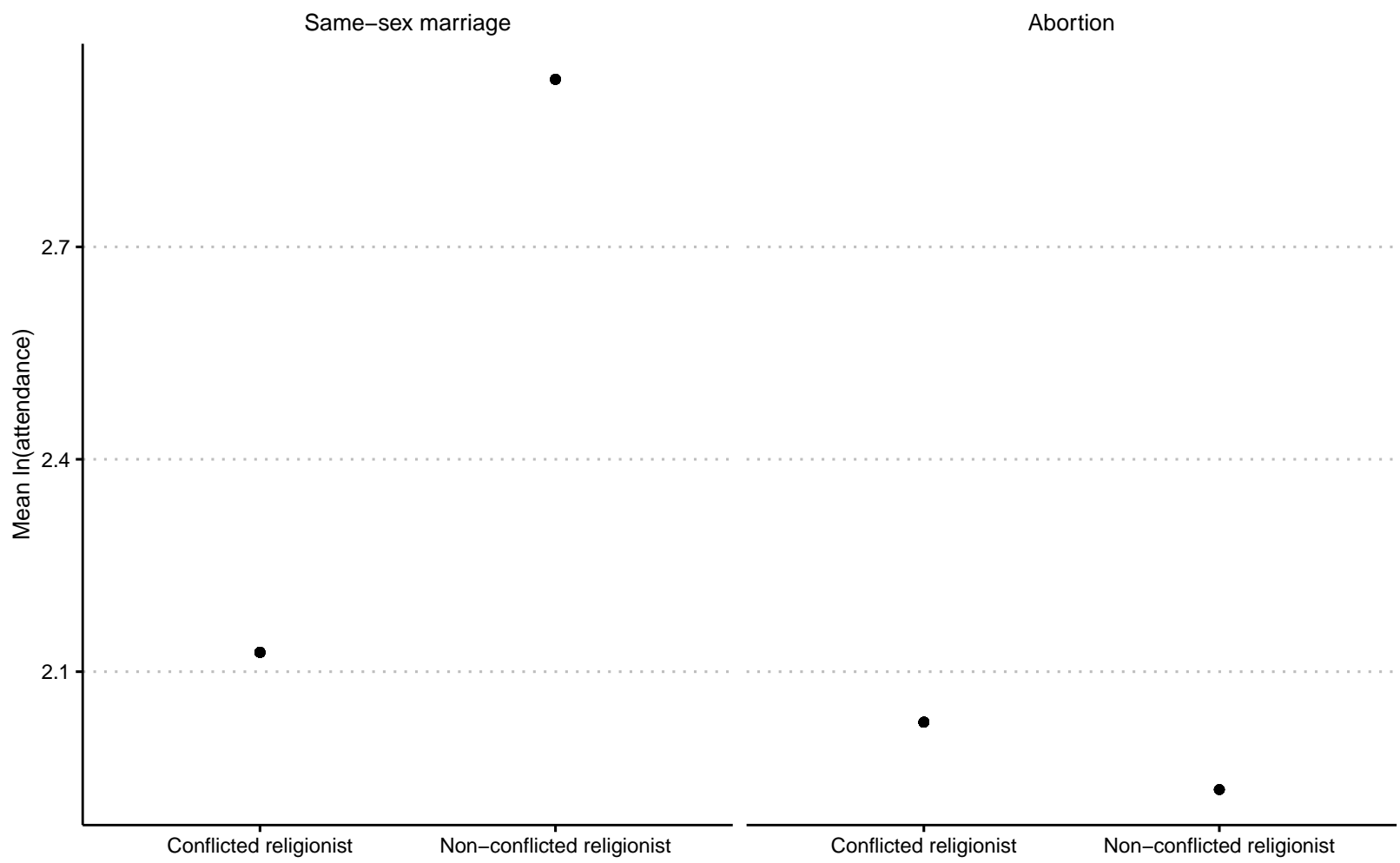

